\title{
A Study of Supply Chain Risk in the Brazilian Wind Power Projects by Interpretive Structural Modeling and MICMAC Analysis
}

\author{
Jorge Arnaldo Troche-Escobar ${ }^{1, *(1)}$, Herman Augusto Lepikson ${ }^{2}$ and \\ Francisco Gaudêncio Mendonça Freires ${ }^{3}$ \\ 1 Postgraduate Program in Industrial Engineering (PEI), Federal University of Bahia (UFBA), \\ Salvador (BA) 40210-630, Brazil \\ 2 National Industrial Learning Service (SENAI-CIMATEC), Av. Orlando Gomes, 1845-Piatã, \\ Salvador (BA) 41650-010, Brazil; herman@ufba.br \\ 3 Polytechnic School, Federal University of Bahia (UFBA), Salvador (BA) 40210-630, Brazil; \\ gaudenciof@yahoo.com or francisco.gaudencio@ufba.br \\ * Correspondence: jorge.troche@gmail.com; Tel.: +55-75-3491-2139
}

Received: 18 August 2018; Accepted: 12 September 2018; Published: 27 September 2018

\begin{abstract}
This paper aims to present an approach to the supply chain risk modeling of Brazilian wind power projects. Risk factors were assessed by literature review and analysis through the Interpretive Structural Modeling (ISM) and the Matrix-based Multiplication Applied to a Classification (MICMAC) methodologies, with a group of professionals of the field. The ISM model represented the relationships between twenty-two risk factors, and their position in the system, from higher to lower-level risks. The MICMAC analysis identified independent, autonomous, linkage and dependent risk factors according to their driving and dependence power. Data collected also allowed for the recognition of indirect influences between risk factors, complementing the system's understanding, in special the strongest linkages. The paper also integrated both outputs to create a better representation of the risks factors into the system. The research characterizes current risk factors' status on the Brazilian wind power supply chain, and the understanding of their implications into the system. It is a guide to implement effective mitigation strategies into the supply chain and more accurate and cautious decision-making in organizations.
\end{abstract}

Keywords: wind power; supply chain; risk factor; interpretive structural modeling; risk management; Brazil

\section{Introduction}

The improvement of technology of alternative energy sources has expanded the energy market in recent years [1]. Technological and economic factors are consolidating sustainable sources such as wind power and solar photovoltaic systems into the energetic matrix of many countries, increasing the development of new projects. In Brazil, wind quality and government incentives help to consolidate a local supply chain [2] and have attracted investment by national and international companies on technological development and supply chain expansion. The development of new facility projects faces increasingly competitive challenges from many sources. Globalization, shorter lead times, and increasing number of new suppliers are demanding dynamic management, effective and faster responses, and cost efficiency control [3]. The supply chain management of wind power projects needs to focus on the identification and mitigation of vulnerability involved in the processes.

A supply chain includes all the steps (direct and indirect) required to fill in the customer's requirement. To Chopra and Meindl [4] it involves the movement between manufacturers, suppliers 
and customers, not only of products, but also of information, funds, and goods in both ways. Due to market requirements and positive environment, the Brazilian wind power projects are expected to keep growing in the coming years [5,6]. Wind farms operating in the country are onshore and positioned in remote places as in the South and Northeast, far from industrial centers and local manufactures [2]. The development of projects requires the allocation of big structures as parts and components, allocation of machinery as big cranes, availability of prepared professionals and coordination of different stakeholders. Wind power supply chain faces a set of uncertainties that disturbs the projects normal development. The uncertainties on the supply chain are defined as risk factors [7] and their sources can lead to disruptions, where strategies are not easy to plan due to the complexity of risks interactions into the system. Wind towers are formed by big structures to support generators and its parts and components, including the blades, rotor and nacelle. The planning to move from local or international manufacturers, which requires the participation of many stakeholders and involves a variety of risk sources. During the transportation of parts and components, there are many possibilities of disruption due to the process itself, but also it is necessary to understand that other risk sources could affect it as well. The importance of risk management of wind power industry is also associated with the continuing growth of the industry and its strategic importance on many countries [8-10].

As in most countries, the Brazilian wind power market is characterized by the participation of many international stakeholders, as turbine manufacturers operating in the biggest wind power producer countries. Wind parks can be also considered to be the latest wind power technology, with continuous innovations in capacities and design of parts and components to improve efficiency. Some of the vulnerabilities confronted on many countries into the wind power supply chain are relatively the same, such as in China, India, USA, Brazil and others. At the same time, each country will represent a unique scenario with its own characteristics, administrative regulations, tax incentives, local technological development of parts and components or different transportation models. These factors highlight the need to develop local studies of supply chain risk issues, to understand the industry progress and assist on the development of strategies by governments and companies.

This paper develops structural analysis methods to study the interaction of several risk factors into the Brazilian context. A structural analysis reduces systems complexity representing direct and indirect relationships between variables. Structural analysis shows a big picture of the observed scenario, where is useful to understand the most important characteristics to design strategies. The aim is to examine the Brazilian wind power supply chain and the risk factors into the system. The study was conducted with a group of experts and a set of risk factors selected from a literature review. The methodology combines two structural analysis techniques, interpretive structural modeling and a matrix-based multiplication applied to a classification analysis.

The paper is organized into five sections. The literature review is presented on Section 2, where a set of risk factors are identified and selected and the two structural methods are briefly described. Section 3 describes the structural analysis methodological procedure to model the risk factor interaction systems. Section 4 discusses the main results, and Section 5 presents the conclusions of the study. Some tables are shown in Appendixs A and B, due to their extension and to make easy the reading and interpretation of their content.

\section{Literature Review}

\subsection{Wind Power Supply Chain Risk Factors}

The concept of risk is widely employed in many fields of study, such as insurance [11], natural disasters [12,13], portfolio management [14], operational risks [15] or conflict management [16], just to name a few. Exploring the definition of risk, we could not find a consensus in the literature that can be applied in all fields and, in some fields, there is not a common definition. According to Pfohl et al. [17], risk in a supply chain can be defined based on two perspectives, by their causes 
and by their effects. A supply chain risk definition by their causes refers to deficits of information concerning prospective situations and events, while a definition related by their effects focus on the consequences of a decision [17]. In this paper, through an analysis of the Brazilian wind power supply chain, we are referring to risk factors by their causes associated with negative scenarios with potential undesired consequences. Decision making under risks is understood as more uncertain and usually related to missing the goal, but in specific contexts, it can be transformed into opportunities. Risk management is decision making within the acceptable limits of risk, which aims to adopt best practice in infrastructure, policies and methodologies that enable more efficient management [18]. It is important to note that, in fact, all aspects of a company are exposed to risks, which are often out of control $[19,20]$. Risk management aims to develop procedures to control, minimize or even eliminate the risk into the system [21].

Establishing the list of risk factors was a critical stage of the research. As the Brazilian wind power supply chain shares some characteristics with other countries, the risk identification was defined by literature review from international sources, combined with observation from participants of a research group on supply chain risk and sustainability management. The literature review also allows for the inclusion of the most significant risk sources without limiting the work to a specific country or context. The purpose was to obtain qualitative information from scientific publications and not the quantification of the studies on the topic. The search was developed into the main scientific databases and prioritized sources of the last five years to retrieve the most recent information. A preliminary list was examined by participants of the research group with expertise into the field, who agreed that the risk factors retrieved from the literature were significant to develop the exploratory study.

There are many approaches for the identification of risk factors in the literature. Gatzert and Kosub [7] proposed grouping risk factors into seven categories: strategic/business risks, transport/construction/completion, operation/maintenance, liability/legal risks, market/sales risks, counterparty risk, and, policy and regulatory risks. Christopher and Peck [22] differentiate between internal and external supply chain risks. Internal risks sources to the supply chain includes cross-companies and in-company causes, while external sources are predominantly exceptional [22]. According to Chopra and Sodhi [23] the potential supply chain risk factors could arrive from a variety of sources, as they identified nine categories: disruptions, delays, systems, forecast, intellectual property, procurement, receivables inventory and capacity. Chopra and Sodhi also identified 28 drivers or risk factors into those nine categories. Many potential sources show the need to identify and select the most representative for each case. The literature review was developed to identify the main risk factors to the Brazilian wind power projects supply chain inside the potential groups and categories. The results are synthetized in Table 1, where some examples of each risk factor are listed.

A supply chain of wind power projects is susceptible to a variety of risks factors. Twenty-two risk factors were identified into the literature. A wind power project is developed to make profit, so many studies cover the Financial risks. Risk sources can affect the financial plan and the projects' cashflow and need to be identified and mitigated [24-26]. Financial issues are complex, and really impact all the projects' development, as well as the contracts compliance. Labor force risks involve unavailability due to lack of trained professionals, which is more critical in the construction stage, while operation and maintenance job demands are stable during the wind farm's life cycle [27]. A lack of trained and prepared technicians adapted to the continuous innovative wind power systems is a risk to its market growth. Technology risks are related to innovations, and technology life cycle that impact local policies and requirements of parts and components $[28,29]$. Wind generators evolved in recent years and new materials for towers and blades allow greater capacities in energy, but at the same time, they could represent new sources of technological risk. Public opposition risks are broadly related to the location of wind farms, noises and potential conflicts. Public acceptance of renewable sources is strongly positive in Brazil, but in poor regions as in the Brazilian Northeast, physical and economical marginalization of people, land appropriations to projects, and failure in government polices to allocate benefits need to be reviewed to ensure better supports [30,31]. Supply risks are related 
to general supply and decision making in logistics, which includes local and international stakeholders' collaboration and knowledge transfer [32]. The wind power industry expansion also developed local suppliers of parts and components, that increased the complexity of the system. Transport risks of parts and components in onshore wind projects are due to the accessibility in remote places where transportation models and infrastructures need to be improved [33,34].

Construction risks include events that cause delays in the preparation and assemblage of the wind parks. Lack of equipment (such as cranes), some parts and components, or accidents are just some examples of risk sources on this category [7]. Demand uncertainty risks are related to manufacturers of parts and components, and service planning to accomplish the dynamic environment, where changes in technology and policies affect the demand forecasting [33]. Delay risks involves any source of postponement on the project, which could be due to a lack of coordination between the variety of stakeholders on the project, such as companies, or regional, or local governments [7]. Operation and maintenance risks involve failures and damages in machinery, accidents, failure in maintenance, among others [35]. Natural hazard risks are due to environmental circumstances. Wind towers are exposed to potential onshore critical conditions such as strong winds [36] and earthquakes [37]. Serial damage risks are related to failures with potential to spread within the wind parks, where detection systems and isolation of failures need to be continuously improved to avoid worse consequences [38]. Legal and responsibility risks are related to contracts or legal regulations [7]. Losses by wind quality risks include wind intermittency and climate change effects. Those factors need to be forecasted and their impact in future scenarios need to be studied $[39,40]$.

Interconnexion network failure risks are related to failure in lines and delays to connect the national grid to new projects [41]. Energy price variation risks are related to regulatory and market conditions, where projects are contracted by auctions [7]. Third-party service risks are related to failure in coordination as potential source of uncertainties, since wind park projects requires participation of specialized third-party companies [35]. Ecological damage risks are environmental consequences pointed to wind parks. Some concerns on the Brazilian market are birds' migration routes, bats habitats and noises by large parks [42,43]. IT/communication risks are related to failures on communication systems, data access, and other critical equipment failure that could be critical to wind tower efficiency [7,35]. Public policy and regulatory risks are identified as barriers, such as delays in processing documentations, changes in regulatory laws that affect future projects and difficulties in fostering a dynamic coordination into the project [7]. Quality risks are related to standards and implies delays on operation until the trouble is solved, including replacement or repairs $[28,29]$. Security risks are concerned to the countries' strategic energy network, and wind parks are exposed to several sources of damages, from theft to cyber-attacks, affecting not only infrastructures but also the workers [44].

\subsection{Interpretive Structural Modeling: Applications and Features}

The interpretive structural modeling (ISM) methodology was developed by John N. Warfield, between 1971 and 1974 [45] and is based on the principles of comparison in pairs. A set of variables placed into a complex system can be compared two by two, constructing all combination of pairs. The ISM transforms confused and little-articulated mental structures into well-defined visual models to be employed in multiple applications [46]. The process of transforming causal variables into a model, represent the relationship into the system, and assist on the interpretation and design of action strategies. The ISM employs a systems approach to the decision-making process and is widely employed in management studies [47]. 
Table 1. List of risk factors considered in the study.

\begin{tabular}{|c|c|c|c|}
\hline Code & Risk Factor & Examples of Sources (But Not Limited to) & Source (s) \\
\hline R1 & Financial Risk & $\begin{array}{l}\text { Lack and/or loss of capital. Exchange rate variation. } \\
\text { Cost volatility. }\end{array}$ & [24-26] \\
\hline $\mathrm{R} 2$ & $\begin{array}{c}\text { Labor force } \\
\text { unavailability risk }\end{array}$ & $\begin{array}{l}\text { Lack of trained human resources. Delays due to lack of } \\
\text { management expertise. Including unavailability due to } \\
\text { occupational risk exposure. }\end{array}$ & [27] \\
\hline R3 & $\begin{array}{l}\text { Technology and } \\
\text { innovation risk }\end{array}$ & $\begin{array}{l}\text { Inaccuracies in capacity definition. Technological obsolescence. } \\
\text { Damage and breakage attributable to design or project sizing. }\end{array}$ & {$[28,29]$} \\
\hline R4 & $\begin{array}{l}\text { Public opposition } \\
\text { risk }\end{array}$ & $\begin{array}{l}\text { Potential changes in public opinion. Disagreement to } \\
\text { construction. Conflicts over land use restrictions. Changes in } \\
\text { public policies affecting nearby communities. }\end{array}$ & {$[30,31]$} \\
\hline R5 & Supply risk & $\begin{array}{l}\text { Delays in delivery of local suppliers. Delays on importation. } \\
\text { Price variation of materials and components. }\end{array}$ & [32] \\
\hline R6 & Transport risk & $\begin{array}{l}\text { Breaks during transportation. Accidents. Thefts. Damages. } \\
\text { Natural disasters affecting transportation stage. }\end{array}$ & {$[33,34]$} \\
\hline R7 & Construction risk & $\begin{array}{l}\text { Lack of special equipment as cranes. Machine break. Delays in } \\
\text { supplies (materials and services). Accidents. }\end{array}$ & [7] \\
\hline R8 & Demand risk & $\begin{array}{l}\text { Changes in projects plan. Uncertainty in demand for parts and } \\
\text { components. Service demand uncertainty. }\end{array}$ & [33] \\
\hline R9 & Delays risk & $\begin{array}{l}\text { Project schedule delays. Coordination failure between } \\
\text { third-party companies. }\end{array}$ & [7] \\
\hline R10 & $\begin{array}{l}\text { Operation and } \\
\text { maintenance risk }\end{array}$ & $\begin{array}{l}\text { Facility damages. Machine breakdown. Negligence. Accidents. } \\
\text { Failure on stock of parts to maintenance. } \\
\text { Failures/technological inefficiency. }\end{array}$ & [35] \\
\hline R11 & Natural hazard risk & Severe weather conditions. Storms. Earthquakes. & {$[36,37]$} \\
\hline $\mathrm{R} 12$ & Serial damage risk & $\begin{array}{l}\text { Defects or breakdowns in parts, components or installations } \\
\text { with collateral damage. }\end{array}$ & [38] \\
\hline R13 & $\begin{array}{l}\text { Legal and } \\
\text { responsibility risk }\end{array}$ & $\begin{array}{l}\text { Liability to third-party companies. Legal disputes. Contractual } \\
\text { risks. Complexity in legislation. Delays in the } \\
\text { approval process. }\end{array}$ & [7] \\
\hline R14 & $\begin{array}{l}\text { Loses by wind } \\
\text { quality risk }\end{array}$ & $\begin{array}{l}\text { Uncertainty in wind forecast. Wind picks with enough quality. } \\
\text { Failure in capacity planning. }\end{array}$ & {$[39,40]$} \\
\hline R15 & $\begin{array}{l}\text { Interconnexion } \\
\text { network failure risk }\end{array}$ & $\begin{array}{l}\text { Network infrastructure. Interconnection lines maintenance } \\
\text { failure. Losses and/or lower project profitability due to } \\
\text { connection failures. }\end{array}$ & [41] \\
\hline R16 & $\begin{array}{l}\text { Energy price } \\
\text { variation risk }\end{array}$ & $\begin{array}{l}\text { Uncertainty in rates of future electricity auctions. Seasonality. } \\
\text { Revenue impacts. }\end{array}$ & [7] \\
\hline R17 & $\begin{array}{l}\text { Third-party service } \\
\text { risk }\end{array}$ & $\begin{array}{l}\text { Non-compliance of outsourced services. Breach or lack of } \\
\text { financing of contracted and subcontracted suppliers. }\end{array}$ & [35] \\
\hline $\mathrm{R} 18$ & $\begin{array}{l}\text { Ecological damage } \\
\text { risk }\end{array}$ & $\begin{array}{l}\text { Interruptions in operations caused by ecological issues. } \\
\text { Interference in habitats of endangered species. }\end{array}$ & {$[42,43]$} \\
\hline R19 & $\begin{array}{l}\text { IT/Communication } \\
\text { risk }\end{array}$ & $\begin{array}{l}\text { Interruptions of operation due to communication failure. } \\
\text { Cyber-attacks. Information theft. }\end{array}$ & {$[7,35]$} \\
\hline R20 & $\begin{array}{l}\text { Public policy and } \\
\text { regulatory risk }\end{array}$ & $\begin{array}{l}\text { Uncertainties in energy policy. Potential changes in specific } \\
\text { support policies. Regulations on renewable energy } \\
\text { investments.Complexity in the approval processes. }\end{array}$ & [7] \\
\hline $\mathrm{R} 21$ & Quality risk & $\begin{array}{l}\text { Materials, parts and components without quality to fit } \\
\text { standards. Delays due to replacements attributed to quality. }\end{array}$ & {$[28,29]$} \\
\hline $\mathrm{R} 22$ & Security risk & $\begin{array}{l}\text { Terrorism. Attacks on installations. Equipment theft. } \\
\text { Vandalism. Assaults. }\end{array}$ & [44] \\
\hline
\end{tabular}

Over the years, the ISM has received several contributions regarding its applications and techniques [46]. It helps to understand the supply chain complexity and the need to ensure business success [48]. In recent years, several studies were published on the development of ISM-based models 
for risk management in supply chains. For example, Pfohl et al. [49] developed a ISM model in two case studies with German industry and trade companies; Tummala and Schoenherr [50] established a structured and ready-to-use approach for managers to assess and manage risks in supply chains; Faisal et al. [51] presented an approach to supply chain risk management by understanding the dynamics between enablers to mitigate risk in supply chain; and, Olson and $\mathrm{Wu}$ [52], compared tools to aid supply chain organizations in measuring, evaluating, and assessing risk of potential partners.

\subsection{MICMAC Analysis}

The MICMAC methodology (Matrix-based Multiplication Applied to a Classification) is a structural prospective analysis to study indirect relationships [53]. In a cross relationship, we can observe three variables and their direct influences: variable $A$ influences $B$, and variable $B$ influences $C$, while $A$ and $C$ did not represent a direct influence, but their relationships with $B$ represents an indirect relationship, where any change in A would impact on C. This analysis is also called an exploration of the grey zones [54]. This analysis complements the ISM methodology by exploring one of the limitations frequently pointed to ISM approaches: that it explores the "yes" or "no" relationships and ignores the so-called grey region between 0 and 1 [46].

The MICMAC methodology was developed by Michel Godet and François Bourse [47]. It consists in a structural assessment based on the conductivity index of each factor [55]. A conductivity index is a suggestive information of how independent or dependent a variable is. In this case, the goal is to understand how the observed risk factor could be strongly influenced by the rest of the factors. Many examples of the MICMAC analysis method are found in the literature concerning supply chains, such as the studies of Lamming and Hampson [56] who projected common issues for purchasing and supply chain managers in the context of environmental management in major UK companies. Gorane and Kant [57] developed a case study to identify the driving and dependence power of supply chain management enablers. Bag and Anand [58] developed a green supply chain management model for the rubber goods manufacturing sector. And, Khan et al. [59] analyzed traceability systems in supply chain management through critical success factors. All the previously cited studies integrated the ISM and MICMAC methods to develop their research, and to reach their results and conclusions.

\section{Materials and Methods}

The set of risk factors related to wind power projects identified in the literature (Table 1) were examined to understand their relationship and to identify risk prioritization and managerial insights for the Brazilian wind power supply chain. First, the interpretive structural modeling (ISM) was used for a better understanding of the risk factors interrelationship, and next, a MICMAC analysis was performed to complement the ISM results through the observation of indirect relationships. This study applied the Delphi method to data collection with experts of the Brazilian wind power industry.

\subsection{Participants and Data Collection}

The study aimed to analyze a heterogeneous group of professionals working on the main companies. It was revealed that professionals of the wind power supply chain are distributed in different regions of the country. The Brazilian wind power farms are commonly built in remote places, and the parts and components industry are distributed from the South and Northeast regions. To overcome this barrier, it was necessary to employ the support of communication technology and internet tools. First, a professional profile into the LinkedIn platform was created (linkedin.com). This profile was connected to a professional network linked to the Brazilian wind power supply chain, either from wind farm companies to parts and components manufacturers, including service providers. The developed of a Delphi technique through internet proved to give profound outcomes showing that participants acted freely in giving their answers [60].

There is no consensus in the literature about the number of experts required to construct the group of participants. To Hasson et al. [61] the process of experts' selection is empirical and pragmatic, where 
the focus must be the quality of participants rather than the number. Linstone and Turrof [62] suggested fifteen participants, but they usually vary from 4 to 30. Loveridge [63] highlighted the importance to define a set of criteria to establish the group and give validity to the sample of participants. To develop an analysis of the Brazilian wind power supply chain, we will focus on three criteria: expertise in years of service, position into the companies' structure, and that collaborators must be actively working into companies belonging to the Brazilian wind power supply chain.

In a first contact, potential contributors were invited to confirm their agreement to volunteer participate. Then, they received a Term of Confidentiality, with the commitment that the research will not reveal their identification and the name of the companies. The second round involved pairs of risk factors selected randomly and presented to participants. They were asked to identify a nature of relation between those pairs, either direct, reverse, double or none relationship. The third part of data collection consisted in the understanding of how strong those relationships are considered in each case, for this, participants identified the nature of relationships, from strong to weak.

Figure 1 summarizes the participants' distribution by expertise in years of service into the Brazilian wind power supply chain, where two main groups can be identified. The first group is made up of participants covering one to nine years of expertise (17 participants). Those participants represent $65 \%$ of the sample and are professionals who joined the fast development of the wind power industry in the last ten years. The second group is made up of participants with nine to nineteen years of expertise (35\% of participants), all professionals pioneers of this industry. It is important to highlight that the Brazilian wind power industry support began in 2003, one year after the Program to Encourage Alternative Sources of Energy (Proinfa) was put into effect.

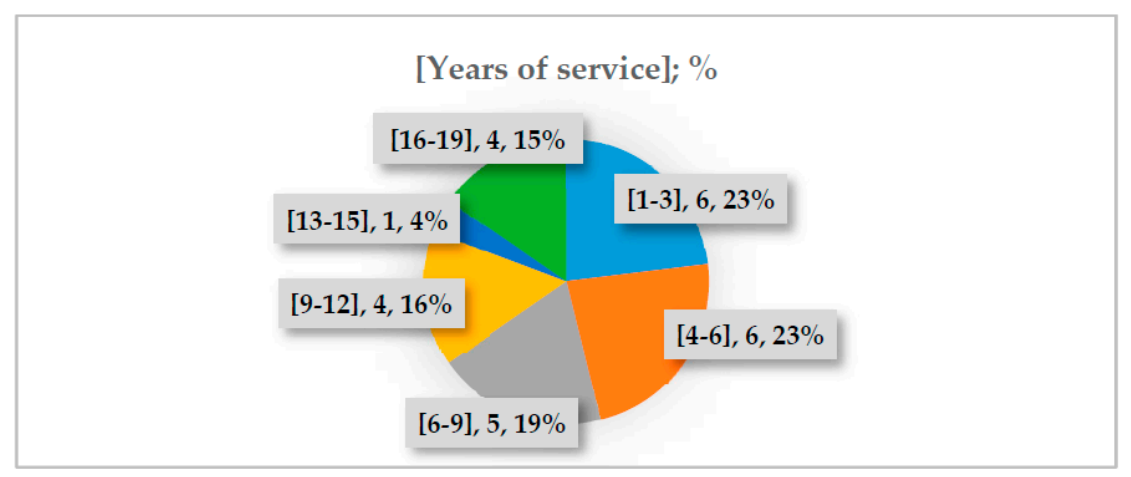

Figure 1. Expertise distribution of participants into the Brazilian wind power supply chain.

Among participants, there were financial and chief operating officers, managers and field technicians. Most of the participants were business managers (5) and electrical engineers (7). Those two groups are related to the main professional tasks and skills required on their jobs. The sample is completed by different engineering fields: civil engineering (2), mechanical engineering (2), production engineering (2), control and automation engineering (1), mechatronic engineering (1). The list is completed by six technicians: electrical (2), electronic (2) and mechatronic (2).

The distribution of participants by gender shows that they were mostly male (25), and only one female. This fact can be understood by the wind power industry characteristics, requiring professionals to frequently perform their activities into remote places, inhibiting female professionals and prioritizing male candidates.

\subsection{Interpretive Structural Modeling}

The data collected with the focal group was the input to develop the interpretive structural modeling (ISM) method. The ISM methodology is based on the application of comprehensive steps, as described in Sushil [46] and Faisal et al. [51]: 
- Identification of variables: a set of risk factors are identified employing techniques as literature review and experts brainstorming (risk variables are listed in Table 1).

- Contextual relationship: It was established between each pair of variables. The self-structural interaction matrix (SSIM) is constructed following the rule: " $\mathrm{V}$ " if the risk variable i leads to the variable $\mathrm{j}$ (direct relationship); "A" when the variable j leads to the variable $\mathrm{i}$ (inverted relationship); " $\mathrm{X}$ " if the relationship between risk variables are in both directions (double relationship); and " $\mathrm{O}$ " when does not exist relationship between the pair of variables.

- Initial reachability matrix: The SSIM matrix is transformed into a binary matrix (0 and 1's) following this rule: a) If the variable $(i, j)$ is $V$, then the variable $(i, j)$ is 1 and the variable $(j, i)$ is $0 ; b)$ If the variable $(i, j)$ is $A$, then the variable $(i, j)$ is 0 and the variable $(j, i)$ is $1 ; c)$ If the variable $(i, j)$ is $X$, then the variable $(i, j)$ and the variable $(j, i)$ takes the value of 1 ; and $d)$ If the variable $(i, j)$ is $O$, then the variable $(\mathrm{i}, \mathrm{j})$ and the variable $(\mathrm{j}, \mathrm{i})$ takes the value of 0 .

- Final reachability matrix with transitivity check: It is a verification step of the reachability matrix. This is made by a logical analysis: If a variable A has relationship with another variable $B$, and, if the variable $B$ has relationship with another $C$; then, it can be concluded that variables $A$ and $C$ have some relationship.

- Definition of levels: The final matrix is converted into a canonical relationship matrix by grouping the elements into their respective levels. The reachability and antecedent sets of variables are constructed from the final reachability matrix. Reachability sets are formed by the factors related (with value of 1) into the horizontal direction while the antecedent sets are obtained from the vertical direction from each risk factor. Intersection points are identified when the same set appears in both columns.

- Construction of the ISM model: The set of variables into their respective levels are linked according to their relationships as defined by the self-structural interaction matrix.

\subsection{MICMAC Analysis}

To develop a MICMAC analysis, we applied the LIPSOR-EPITA-MICMAC@ software (version 6.1 .2 of 2003/2004), that is freely distributed by creative commons license by La prospective organization (www.laprospective.fr) [64]. The software was developed in France, by the IT innovation institute (3IE) of the Graduate School of Computer Sciences (EPITA).

It was defined a relationship scale represented into the direct relationship matrix (Table A3). The participants were asked to identify how strong or weak is the relationship between the pairs of risks. We use three levels as represented in Table A3 to match with the software input formatting: strong (denoted by 3), moderate (denoted by 2), and weak (denoted by 1). Data from Table A3 were inputted into LIPSOR-EPITA-MICMAC@ software and ran to stabilize the direct relationship matrix. Two reports will be explored on this study: the map of influences (also cluster of variables) and the indirect relationship that represents relationships from weak to strong, identifying variables interacting with the greatest number of connections and variables with less interactions on the system.

The map of influences represents the variables in four quadrants or zones. Those zones are defined as: zone I, variables that are considered autonomous, that is, risk factors that has no dependence or weak dependence on another risk factor; zone II, variables that are predominantly dependent, that is, the appearance of another risk factor would probably conduct those risks to happen; zone III, are the connecting variables, that is, variables that most influence others; and zone IV, the most independent variables into the model, that is, risk variables that receive weak influence from others variables, but are not completely autonomous as risk factors in zone I. The second report, the indirect relationship graph, will be discussed only using the strongest indirect influences. 


\section{Results}

\subsection{Interpretive Structural Modeling}

Data collection occurred between December 2017 and May 2018 and involved the participation of 26 professionals from different companies. Their observations aimed to construct the interaction between the twenty-two risk factors, which represented the examination of 231 pairs of risks. The starting point of the ISM method was the structural self-relationship matrix (Table 2) where each pair of risk factors were identified by the relationship criteria, as $\mathrm{V}, \mathrm{A}, \mathrm{X}$ or $\mathrm{O}$ as described in the methodology.

Table 2. Structural self-relationship matrix.

\begin{tabular}{|c|c|c|c|c|c|c|c|c|c|c|c|c|c|c|c|c|c|c|c|c|c|}
\hline & R22 & R21 & R20 & R19 & R18 & R17 & R16 & R15 & R14 & R13 & R12 & R11 & R10 & R9 & R8 & R7 & R6 & R5 & R4 & R3 & R2 \\
\hline R1 & $X$ & $\mathrm{~V}$ & $X$ & $\mathrm{~V}$ & $\mathrm{~V}$ & $\mathrm{~V}$ & A & A & A & A & A & $X$ & $X$ & $X$ & A & $X$ & $\mathrm{~V}$ & $\mathrm{~V}$ & $\mathrm{O}$ & $\mathrm{O}$ & $\mathrm{O}$ \\
\hline $\mathbf{R} 2$ & $\mathrm{O}$ & $\mathrm{V}$ & A & $\mathrm{O}$ & $\mathrm{O}$ & $\mathrm{V}$ & $X$ & $\mathrm{O}$ & $\mathrm{O}$ & $\mathrm{V}$ & A & $\mathrm{O}$ & A & V & $\mathrm{O}$ & $\mathrm{V}$ & $\mathrm{O}$ & $\mathrm{V}$ & $\mathrm{V}$ & $\mathrm{A}$ & - \\
\hline R3 & $\mathrm{V}$ & $X$ & $\mathrm{~V}$ & $\mathrm{O}$ & $\mathrm{O}$ & $\mathrm{V}$ & $\mathrm{O}$ & $X$ & $\mathrm{~V}$ & A & $\mathrm{O}$ & A & $X$ & $X$ & $\mathrm{~A}$ & $X$ & $\mathrm{~V}$ & $\mathrm{~V}$ & $\mathrm{~V}$ & - & - \\
\hline R4 & A & $\mathrm{O}$ & $x$ & $\mathrm{~V}$ & $X$ & A & A & $\mathrm{O}$ & $\mathrm{O}$ & $\mathrm{O}$ & A & A & A & $\mathrm{V}$ & $\mathrm{A}$ & $X$ & $\mathrm{~V}$ & $\mathrm{~V}$ & - & - & - \\
\hline R5 & $\mathrm{V}$ & A & $x$ & $X$ & $\mathrm{O}$ & $\mathrm{V}$ & $\mathrm{V}$ & $\mathrm{O}$ & $\mathrm{V}$ & $x$ & $\mathrm{~V}$ & A & $\mathrm{V}$ & $\mathrm{V}$ & $\mathrm{A}$ & $x$ & $x$ & - & - & - & - \\
\hline R6 & $x$ & $\mathrm{~V}$ & $\mathrm{O}$ & A & $\mathrm{V}$ & A & V & $\mathrm{O}$ & $\mathrm{O}$ & $\mathrm{V}$ & V & $\mathrm{O}$ & $\mathrm{O}$ & $\mathrm{V}$ & $\mathrm{O}$ & $\mathrm{V}$ & - & - & - & - & - \\
\hline R7 & A & $x$ & A & A & $x$ & A & $\mathrm{O}$ & $x$ & $\mathrm{O}$ & $\mathrm{O}$ & $x$ & $\mathrm{~V}$ & $\mathrm{~V}$ & $\mathrm{~V}$ & $\mathrm{O}$ & - & - & - & - & - & - \\
\hline R8 & $\mathrm{O}$ & $\mathrm{O}$ & A & $\mathrm{O}$ & $\mathrm{O}$ & $\mathrm{V}$ & $\mathrm{O}$ & $\mathrm{O}$ & $\mathrm{O}$ & $\mathrm{V}$ & $\mathrm{O}$ & $\mathrm{O}$ & $\mathrm{V}$ & $\mathrm{O}$ & - & - & - & - & - & - & - \\
\hline R9 & A & $\mathrm{V}$ & A & $\mathrm{O}$ & A & V & $\mathrm{O}$ & $\mathrm{V}$ & $\mathrm{O}$ & V & A & A & $\mathrm{O}$ & - & - & - & - & - & - & - & - \\
\hline R10 & $\mathrm{V}$ & $x$ & A & A & $\mathrm{V}$ & $\mathrm{V}$ & $\mathrm{O}$ & $x$ & $\mathrm{~V}$ & $\mathrm{~V}$ & $\mathrm{~V}$ & $x$ & - & - & - & - & - & - & - & - & - \\
\hline R11 & $\mathrm{O}$ & A & $\mathrm{O}$ & $\mathrm{O}$ & $X$ & $\mathrm{~V}$ & $X$ & $\mathrm{~V}$ & $\mathrm{O}$ & $\mathrm{V}$ & $\mathrm{V}$ & - & - & - & - & - & - & - & - & - & - \\
\hline R12 & V & A & $x$ & $\mathrm{~V}$ & A & $\mathrm{O}$ & $\mathrm{V}$ & $\mathrm{V}$ & $\mathrm{O}$ & $\mathrm{O}$ & - & - & - & - & - & - & - & - & - & - & - \\
\hline R13 & $x$ & $\mathrm{~V}$ & $x$ & $\mathrm{O}$ & A & A & $X$ & $\mathrm{~V}$ & $\mathrm{O}$ & - & - & - & - & - & - & - & - & - & - & - & - \\
\hline R14 & $\mathrm{O}$ & $\mathrm{V}$ & $\mathrm{O}$ & $\mathrm{O}$ & $\mathrm{O}$ & $\mathrm{O}$ & $X$ & $\mathrm{O}$ & - & - & - & - & - & - & - & - & - & - & - & - & - \\
\hline R15 & $\mathrm{O}$ & $\mathrm{V}$ & $X$ & $x$ & $\mathrm{O}$ & $\mathrm{V}$ & $\mathrm{O}$ & - & - & - & - & - & - & - & - & - & - & - & - & - & - \\
\hline R16 & $\mathrm{O}$ & $\mathrm{V}$ & $\mathrm{V}$ & $\mathrm{O}$ & $\mathrm{O}$ & V & - & - & - & - & - & - & - & - & - & - & - & - & - & - & - \\
\hline R17 & $x$ & $\mathrm{~V}$ & A & $\mathrm{V}$ & A & - & - & - & - & - & - & - & - & - & - & - & - & - & - & - & - \\
\hline R18 & V & $\mathrm{O}$ & A & A & - & - & - & - & - & - & - & - & - & - & - & - & - & - & - & - & - \\
\hline R19 & $\mathrm{V}$ & $\mathrm{V}$ & A & - & - & - & - & - & - & - & - & - & - & - & - & - & - & - & - & - & - \\
\hline R20 & $\mathrm{O}$ & $\mathrm{O}$ & - & - & - & - & - & - & - & - & - & - & - & - & - & - & - & - & - & - & - \\
\hline R21 & $x$ & - & - & - & - & - & - & - & - & - & - & - & - & - & - & - & - & - & - & - & - \\
\hline
\end{tabular}

The self-structural matrix is transformed into the binary initial accessibility matrix (Table A1). The assigned values: $\mathrm{V}, \mathrm{A}, \mathrm{O}$ and $\mathrm{X}$, are transformed to equivalents according to the rule described on the methodology (Section 3.2). When a pair is formed by the same variable, as R1 with R1, it is represented by 1 . Once the original binary matrix has been concluded, and before continuing with the process, it is necessary to make a check of the transitivity on it.

This verification consists of: if variable $A$ is related to another $B$, and the variable $B$ is related to another $C$; then the variable $A$ and $C$ are related. The transitivity check is made line by line in Table A1. As result from this checking process, we obtain the Final reachability matrix (Table A2), which identified relationship (indicated by *). As an example, we can observe in Table A1 that R1 is related to $\mathrm{R} 7$, and $\mathrm{R} 7$ is related to $\mathrm{R} 3$, then the interaction $\mathrm{R} 1$ and $\mathrm{R} 3$ (with value of 0 ) is transformed into $1^{*}$ in Table A2.

The analysis of levels of risk factors is done using the canonical matrix (Table A2). The reachability sets are formed from the factors related in the horizontal direction, while the antecedent sets are obtained from the vertical direction for each risk factor. We can examine the case of R1 in Table A2 as an example; The reachability set will be all variables with values of 1 or $1^{*}$ into the rows intersections with R1: R1, R2, R3, R4, R5, R6, R7, R8, R9, R10, R11, R12, R13, R14, R15, R16, R17, R18, R19, R20, R21, and $\mathrm{R} 22$. The antecedent set will be all variables with values of 1 or $1^{*}$ into the columns intersections with R1: R 1, R2, R3, R4, R5, R6, R7, R8, R9, R10, R11, R12, R13, R14, R15, R16, R18, R19, R20, R21, and $\mathrm{R} 22$. Intersection points are identified when the same set appear in both columns. The same process is followed to define all the levels as showed in Tables A4-A10 (Appendix B).

The interpretive structural model is constructed based on the levels identified from Tables A4-A10 (Figure 2). Each variable is placed according to the corresponding level and the relations are established from the top-level variables (bottom of the model) to the lower-level variables (top of the model). 


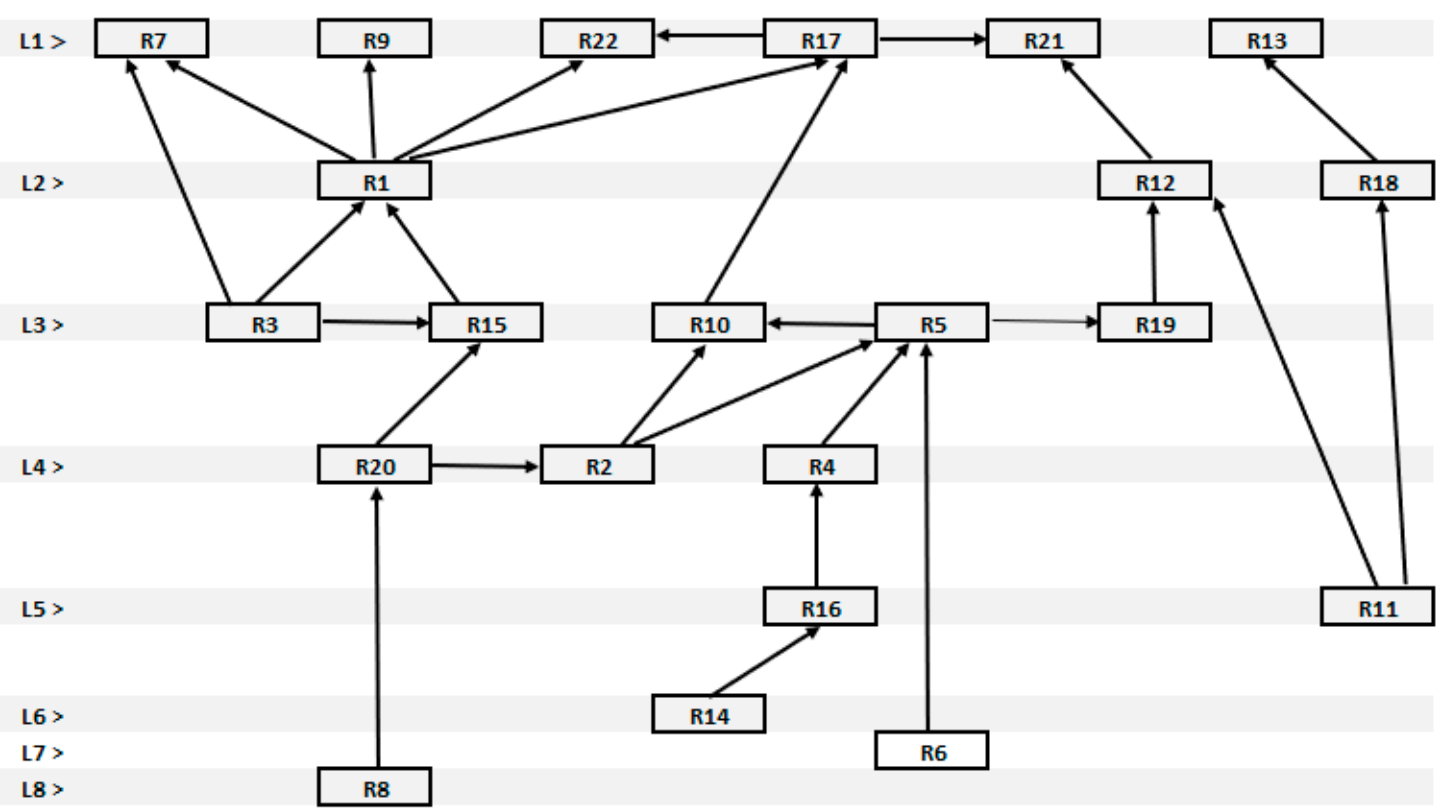

Figure 2. Interpretive structural model to risk factors on the Brazilian wind power supply chain.

\subsection{MICMAC Analysis}

Values from Table A3 are set into the MICMAC software $\odot$ to run the analysis. Risk cluster is represented by the map of influences or MICMAC matrix (Figure 3). On the map of influences, the variables are represented into four zones according to their driving and dependence force. Those four factors zones are: independent (Z1), autonomous (Z2), linkage (Z3) and dependent (Z4).

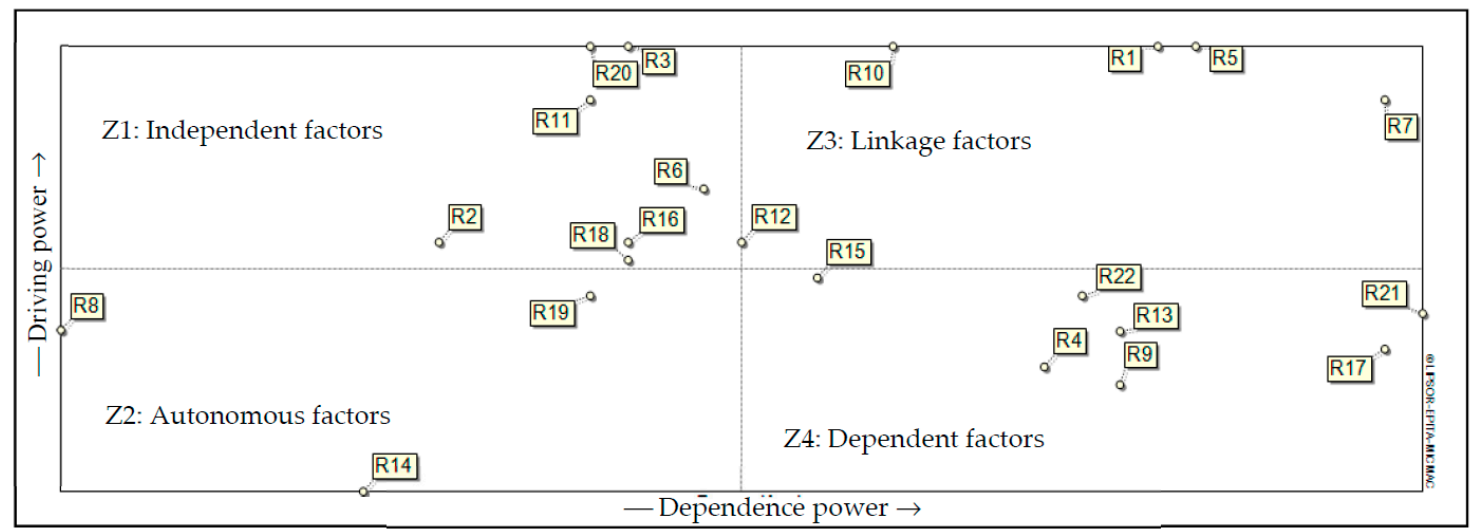

Figure 3. Map of influences/Direct dependencies. Source: Matrix-based Multiplication Applied to a Classification (MICMAC) software ${ }^{\circledR}$ (version 6.1.2; 3IE/EPITA, France).

The information from Figure 3 is employed to generate the graph of indirect influences (Figure 4). This graph represents the intensity of all 231 pair of linkages by their intensity, from strongest to the weakest. To simplify the understanding, Figure 4 shows only two levels; the most important and the strong influences as considered the most important into the system. 


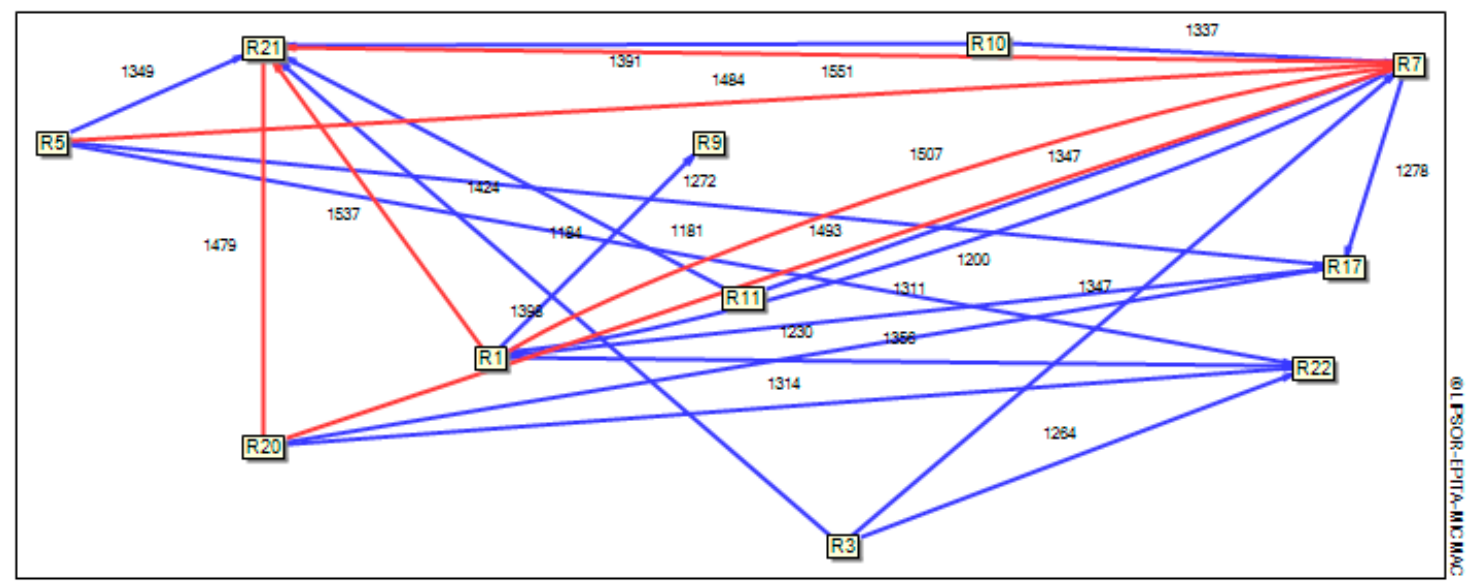

- Strong influences

- Most important influences

Figure 4. Graph of indirect influences. Source: MICMAC ${ }^{\circledR}$ software (6.1.2; 3IE/EPITA, France).

\section{Discussion}

\subsection{Interpretive Structural Modeling}

The interpretive structural model on Figure 2 represents the interaction between 22 risk variables on the Brazilian wind power supply chain. The variables are connected by arrows from the higher-level (bottom of the figure) to the lower-level (top of figure). Risk variables on top of the Figure 2 are influenced by the interconnection of the remaining risk variables. Risk variables on the bottom are risk factors not influenced by any other risk of the system, but instead, their appearance affects the entire structure. The basis of the model shows risk factors outside control of the system and established by external variables, as environmental conditions or policies defined by governments.

Four risk variables: Demand risks (R8), Risks by losses due to wind quality (R14), Transport risk (R6) and Natural hazards risk (R11) are in the bottom of the system. In fact, environmental dimensions, as wind variation and extreme natural conditions are not under control by the companies. The demand of parts and components as an external risk factor is due to the continuous growth feature of wind power projects, and according to the participants observation, the demands depend on energy auctions defined by the government. Risk by transportation as another external factor indicates that movement of parts and components are managed by third-party specialized companies in charge of this operation.

Demand risk (R8) has direct linkage with Public policy and regulatory risk (R20). Wind power projects will keep expanding in the coming years, increasing the demand of parts and components, and influencing the definition of public policy focused on incentives, as tax reduction, public funding, and attraction of investment. Public policy and regulatory risk (R20) have direct linkage to Interconnection networks failure (R15) and Labor force unavailability (R2). In fact, those risk factors have a direct relationship to the public policy on improving the Brazilian national interconnection system, to maintain a required level of trained workers to support the projects. Labor force unavailability (R2) influences two risk factors: Operation and maintenance risk (R10) and Supply risk (R5), otherwise, an absence of trained workers would influence those two main functions of the wind power supply chain, the operation and supply of wind power projects.

Losses due to wind quality (R14) was identified as linked to the energy price variation risk (R16), and this to the public opposition risk (R4). Wind projects are commissioned by energy auctions by the Brazilian government's regulatory institution. Those auctions depend on projections of the energy market and on the capacity to fulfill future demands. On this sense, energy price is the key to maintain infrastructure investments. The relationship between public opposition (R4) and energy price (R16) could be an indicator that wind power projects investments are perceived mostly as positive by public opinion in Brazil, creating direct and indirect employment and improvements in infrastructure in 
remote places. The link between public opposition (R4) and supply risk (R5) could be to the fact that an opposition must hinder investments and supply to the projects.

Transport risk (R6), coordinated by specialized third-party companies, is connected to supply risk (R5). This relationship shows a third component influencing the supply of parts and components. As mentioned before, the characteristic of the Brazilian country and onshore wind power facilities, places the transportation as a key function into the analyzed system. The last risk factor on the bottom, Natural hazards risk (R11) deals with serial damages (R12) and ecological damage risk (R18). Those relationships are easy to understand since severe conditions are one of the sources of serial damages into wind parks and the ecological damages caused by wind parks structures.

Six risk factors are on the top of the model that represents the lower-level of the system. Construction risk (R7) is impacted by technology and innovation risk (R3) and financial risk (R1). On this section we also have a triangular linkage between technology and innovation risk (R3), financial risk (R1) and interconnection network failure risk (R15). Financial risk (R1) as can be expected presents a greater number of links because the lack of available funding will impact contracts management, leading to construction risk (R7), delays risk (R9), security risk (R22) and third-party service risk (R17). Operation and maintenance risk affect directly third-party service risk (R17) and third-party service risk (R17) leads to security risk (R22).

Quality risk (R21) is affected by two risk factors, third-party service risk (R17) and serial damage risk (R12). The support of third-party companies represents technical assistance, maintenance and advisory services, otherwise, a set of supporting service to guarantee the expected quality of operations of wind projects. The second risk factor affecting quality is serial damage (R12), conducted by IT/communication risk (R19) and natural hazard risk (R11). Serial damages can be critical on wind parks, due to the time and effort that could be needed to fix the damages and recover the energy generation levels. The last factor is the legal and responsibility risk (R13) that was identified in direct relationship with ecological damages risk (R18). This linkage shows the importance of ecological guidelines accomplishment by the projects. This could be the source of legal implications causing heavy penalties.

\subsection{MICMAC Analysis}

The MICMAC analysis is based on the strength of the relationship between risk variables. As results of the linkage levels we obtained two reports, the map of influences (Figure 3) and the graph of indirect influences (Figure 4). The map of influences divides risk variables in four zones according to their driving and dependence power. Driving power is a capacity of the variable to conduct risk to or from other variables, while dependence power is the capacity to absorb risk from other risk variables. The four zones and the risk factors are:

- $\quad \mathrm{Z} 1$, independent factors: on this zone lies seven risk variables, around $32 \%$ of risk factors. This zone represents variables that are little dependent but most conductive. Variables on this zone are labor force unavailability risk (R2), technology and innovation risk (R3), transport risk (R6), natural hazards risk (R11), energy price variation risk (R16), ecological damage risk (R18) and public policy and regulatory risk (R20). Some transformation on those risk factors on this zone would affect the whole system. It is important to understand which variables can be prioritized to design mitigation strategies by the companies on this zone. Transportation risks (R6) and Technology and innovation risk (R3) could be monitored to implement action strategies to guarantee a better performance of the system. Variables not under control need to be supervised, in an attempt to prevent changes and improve mitigation strategies, as natural hazards (R11) and public policy and regulatory risks (R20).

- $\quad$ Z2, autonomous factors: this zone identified three risk factors, demand risk (R8), losses by wind quality risk (R14) and IT/communication risk (R19). Those risk factors, with less conductivity and dependence on the system, are variables that demand less attention at the current situation. The Brazilian wind power industry is expected to keep growing, which is the reason why factors 
such as demand, and wind quality are considered under control and do not represent considerable risk levels to the system. The wind power projects are characterized by high investment in the latest technology, including implementation of IT/communication technologies, which qualifies them as autonomous risks into the system.

- Z3, linkage factors: this zone is characterized by risk factors that are most conductive and dependent. That is, variables affected by changes into the system, and at the same time, conducting to others. Those risk variables are positioned usually in the middle of the model linking the top and bottom levels. Four risk factors (around 18\%) were identified into this zone: financial risk (R1), supply risk (R5), construction risk (R7) and operation and maintenance risk (R10). A change into those risk variables leads to instability into the system.

- Z4, dependent factors: with seven risk factors (32\%); public opposition (R4), delays risk (R9), legal and responsibility (R13), interconnection network failure risk (R15), third-party service risk (R17), quality risk (R21) and security risk(R22). Those risk factors are characterized by their high dependence, absorbing more easily the changes on the system, but at the same time, lower conductivity. Those variables can be followed as indicators of the stability on the system, because the observation of changes on those variables could indicate any other factor affecting the system stability.

A special case can be observed on serial damage risk (R12), on the middle between independent and linkage factors. This variable is intermediate on dependence but higher on conductivity, but is located between two zones, Z1 and Z3. Potential serial damages need attention on the design of strategies to maintain the system without important impacts on the analyzed risk factors. We can observe a relatively balanced distribution of risk variables in the driving power or the dependence power individually. Twelve risk factors lie above the midline and ten under the middle of the driving power scale. Similarly, twelve risk factors are on the right side of the middle dependence power and ten risk factors in the left.

When a great number of risk factors interact into the system, there are not only direct linkages. To study the system's complexity, we need to observe the indirect influences to obtain a complete overview of the interactions. The graph of indirect influences (Figure 4) represents the strongest levels of influences. The observation of indirect influences provides understanding of changes that could happen in the future between the interactions. If the strongest influences are maintained in the coming years, they have potential to become direct influences, while moderate influences can also be understood as links with potential to be stronger as some changes are introduced into the system.

Two risk factors on Figure 4 receive the strongest indirect influences: construction risk (R7) and quality risk (R21). Those risk factors were also classified as lower level into the ISM (Figure 2) and with highest level of dependency on the map of influences (Figure 3). Construction risks are linked with supply risk (R5), public policy and regulatory (R20) and financial risk (R1). Then, the achievement of construction standards also depends on a strong influence by the supply of materials, public and regulatory factors, as environmental studies developed before licensing the construction and the financial security to achieve contract schedules.

Quality risk (R21), also receives strongest indirect influences by three risk factors, construction risk (R7), public policy risk (R20) and financial risk (R1). Some of the risk factors are constant comparing the observed construction risks (R7). This result shows the importance of public policy and financial factors into the Brazilian wind power supply chain. The increase in generation is not only due to natural conditions such as wind quality but are more related to strategic decisions taken to support the supply chain of wind projects.

\subsection{Risk Management Implications}

The results represent the understanding of the participants from the wind power projects and not from a specific company. They represent a current picture of the Brazilian wind power supply chain. The study of direct and indirect influences, by ISM and MICMAC, are important tools for 
decision makers, and useful not only to companies, but also to guide policy planning for local or regional governments, and to develop strategies to attract and support investments. An important risk factor identified in a specific scenario, such as transportation risk, can be discussed to find mitigation alternatives between the stakeholders and improve its performance into the system.

As the current market is characterized by its volatility, especially according to international commerce agreements, companies need to evaluate risks affecting the activities on a continuous way. The process can lead to important decision making on the projects. As an example, when third-party companies represent an important risk factor in a context, the company can identify which partners represents higher dependence and search alternatives, as to identify potential new partnerships or to help developing local companies to diversify its portfolio as a strategic movement.

Figure 5 combines the ISM and MICMAC graphs where risk factors are represented by color identifying the zones. The ISM applies to the direct relationship, while MICMAC analysis contemplates indirect levels between those relationships. The strongest indirect influences are linked to construction risk (R7) and quality risk (R21). The serial damages risk factor (R12) lied between two zones (independent and linkage), which is the reason why it is represented by a special color.

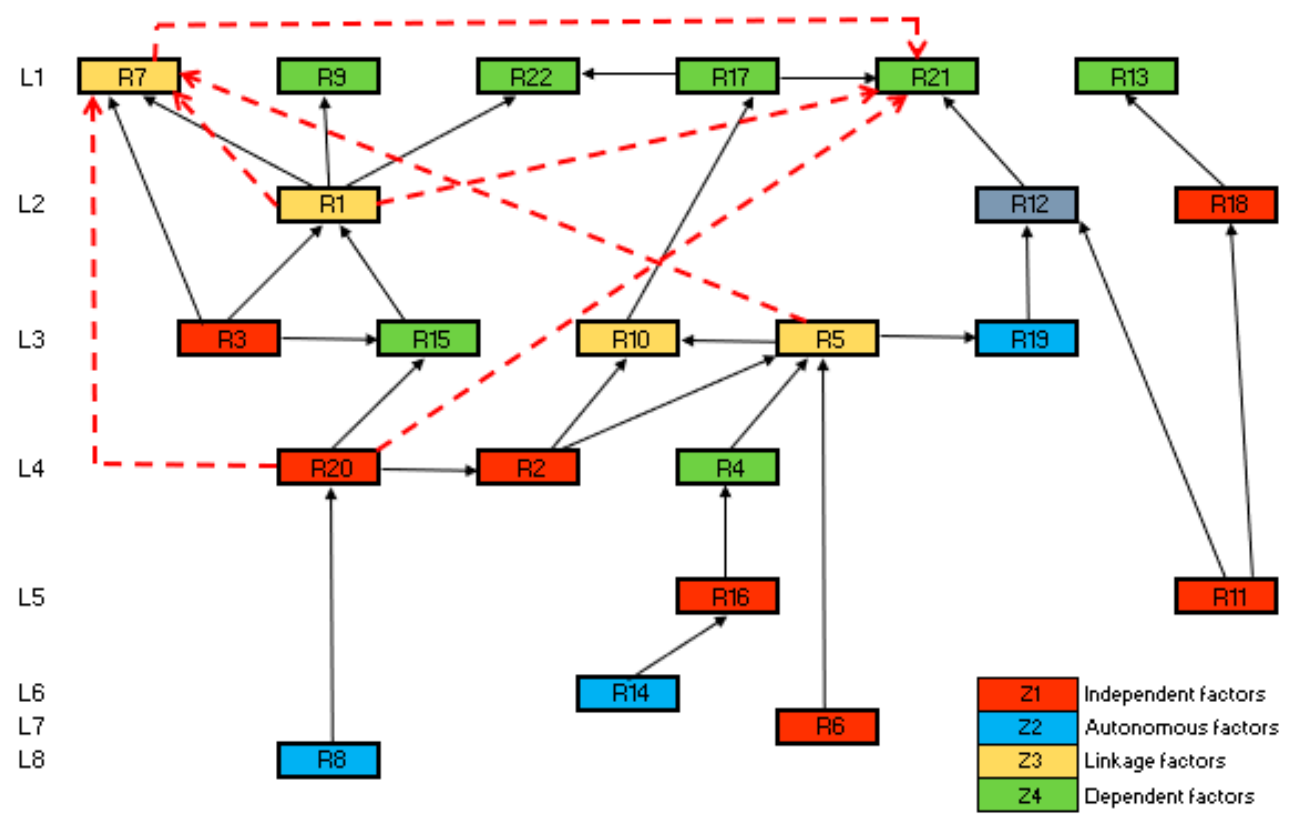

Figure 5. Combined results from Interpretive Structural Modeling (ISM) and MICMAC graphs.

Risk factors on top of the ISM are variables under less control by the system. Those variables depend on external factors, not under control by companies on the system and most difficult to handle. Natural hazards and wind quality can be analyzed using environmental studies or historical data, and the mitigation strategies could consist of insurance plans. The result of demand and transport on top levels could represent external stakeholders regarding the interviewed professionals. Demand of part and components has direct relation to energy projects commissioned by the government, while transportation is managed by third-party companies, which were not considered on this study. The mitigation strategy of transportation risks could be also complex, because most of the projects are in remote places, with limited infrastructure to support the translation of big structures, as blades, generators, hubs and towers. Local governments are key actors in defining mitigation strategies and improving infrastructure conditions.

The MICMAC analysis divided risk factors in groups. A first step to ensure the success of wind power projects depends on the control of risk factors that are more conductive (higher driving power). Those variables are more unpredictable on the way they affect the system, influencing other risk factors more easily. The focus on mitigation of driving risks could represent an isolation of risk variables 
before their spread to other factors. Also, risk factors with more dependence power, that are more easily affected by any change into the system and absorb their impacts.

\section{Conclusions}

The study presented here aimed to analyze a set of risk factors identified in the literature about wind power supply chain projects. They were evaluated with a group of experts that compared those risk factors in pairs to generate data to a structural analysis by ISM and MICMAC methodology. The information represents an important understanding of risk factors and their implications in the wind power system into the Brazilian context. This understanding allows for more accurate and cautious decision making in organizations, helping to focus efforts on the implementation of more effective mitigation strategies and improve the supply chain.

Since the supply chain is influenced by uncertainties, studies to identify risk factors and modeling their interactions are increasing in importance. Two characteristics of risk factors were discussed on this paper. First, the level of risk into ISM representation. Lower risk factors of the model are affected by a greater number of factors, while top of the model represents risk factors not under control by the sample of companies represented by the participants. A second characteristic was the conductivity of risk factors into the system. Risk factors with better conductivity must receive more attention in the first stage. The capacity to conduct risk into the system could impact the supply chain in most unpredictable way. While independent variables receive less influence, linkage variables are most conductive and dependent of risks into the supply chain. In second place, risk variables with lower driving power and high dependence power. Those risk factors are critical being affected more easily, while the autonomous risk variables have less interaction into the system.

As presented throughout the paper, the ISM-MICMAC approach developed on this study has advantages when applied to complex systems, such as the Brazilian wind power supply chain. Both methods were applied to a systemic process, and participants needs to focus on the pair of variables instead of knowing all the process. The results represent the view of a group of participants, as the process assist participants to reflect on the importance of the development of a structural analysis, graphical models and matrices, which are useful in the understanding and discussion of their characteristics, to identify key issues, and to develop mitigation policies.

The study has limitations associated with structural analysis and expert groups participation. Experts' opinions are important to understand a system, but they are nonetheless subjective data from a focal group. A combination of participants from different companies and regions was the strategy used, aiming to collect a wide range of information. This research is going to continue by exploring mitigation strategies with stakeholders and exploring their objectives and limitations in the system.

Author Contributions: This paper received the individual contribution of each author as specified: J.A.T.-E. and F.G.M.F. conceived of and designed the research; J.A.T.-E. developed the research, lead data collection and analysis, and wrote the paper. F.G.M.F. and H.A.L. reviewed and made corrections to improve the paper. All authors read the full paper and agreed with its publication.

Funding: This study was financed in part by the Coordenação de Aperfeiçoamento de Pessoal de Nível Superior-Brasil (CAPES)_Finance Code 001.

Acknowledgments: The authors would like to acknowledge the professionals who collaborated on this study. We would also like to thank all the reviewers who provided suggestions to improve this paper.

Conflicts of Interest: The authors declare no conflict of interest. 
Appendix A

Table A1. Initial reachability matrix.

\begin{tabular}{|c|c|c|c|c|c|c|c|c|c|c|c|c|c|c|c|c|c|c|c|c|c|c|}
\hline & $\mathbf{R} 1$ & $\mathbf{R} 2$ & R3 & R4 & R5 & R6 & R7 & R8 & R9 & R10 & R11 & R12 & R13 & R14 & R15 & R16 & R17 & R18 & R19 & R20 & R21 & R22 \\
\hline R1 & 1 & 0 & 0 & 0 & 1 & 1 & 1 & 0 & 1 & 1 & 1 & 0 & 0 & 0 & 0 & 0 & 1 & 1 & 1 & 1 & 1 & 1 \\
\hline $\mathbf{R} 2$ & 0 & 1 & 0 & 1 & 1 & 0 & 1 & 0 & 1 & 0 & 0 & 0 & 1 & 0 & 0 & 1 & 1 & 0 & 0 & 0 & 1 & 0 \\
\hline R3 & 0 & 1 & 1 & 1 & 1 & 1 & 1 & 0 & 1 & 1 & 0 & 0 & 0 & 1 & 1 & 0 & 1 & 0 & 0 & 1 & 1 & 1 \\
\hline R4 & 0 & 0 & 0 & 1 & 1 & 1 & 1 & 0 & 1 & 0 & 0 & 0 & 0 & 0 & 0 & 0 & 0 & 1 & 1 & 1 & 0 & 0 \\
\hline R5 & 0 & 0 & 0 & 0 & 1 & 1 & 1 & 0 & 1 & 1 & 0 & 1 & 1 & 1 & 0 & 1 & 1 & 0 & 1 & 1 & 0 & 1 \\
\hline R6 & 0 & 0 & 0 & 0 & 1 & 1 & 1 & 0 & 1 & 0 & 0 & 1 & 1 & 0 & 0 & 1 & 0 & 1 & 0 & 0 & 1 & 1 \\
\hline R7 & 1 & 0 & 1 & 1 & 1 & 0 & 1 & 0 & 1 & 1 & 1 & 1 & 0 & 0 & 1 & 0 & 0 & 1 & 0 & 0 & 1 & 0 \\
\hline R8 & 1 & 0 & 1 & 1 & 1 & 0 & 0 & 1 & 0 & 1 & 0 & 0 & 1 & 0 & 0 & 0 & 1 & 0 & 0 & 0 & 0 & 0 \\
\hline R9 & 1 & 0 & 1 & 0 & 0 & 0 & 0 & 0 & 1 & 0 & 0 & 0 & 1 & 0 & 1 & 0 & 1 & 0 & 0 & 0 & 1 & 0 \\
\hline R10 & 1 & 1 & 1 & 1 & 0 & 0 & 0 & 0 & 0 & 1 & 1 & 1 & 1 & 1 & 1 & 0 & 1 & 1 & 0 & 0 & 1 & 1 \\
\hline R11 & 1 & 0 & 1 & 1 & 1 & 0 & 0 & 0 & 1 & 1 & 1 & 1 & 1 & 0 & 1 & 1 & 1 & 1 & 0 & 0 & 0 & 0 \\
\hline R12 & 1 & 1 & 0 & 1 & 0 & 0 & 1 & 0 & 1 & 0 & 0 & 1 & 0 & 0 & 1 & 1 & 0 & 0 & 1 & 1 & 0 & 1 \\
\hline R13 & 1 & 0 & 1 & 0 & 1 & 0 & 0 & 0 & 0 & 0 & 0 & 0 & 1 & 0 & 1 & 1 & 0 & 0 & 0 & 1 & 1 & 1 \\
\hline R14 & 1 & 0 & 0 & 0 & 0 & 0 & 0 & 0 & 0 & 0 & 0 & 0 & 0 & 1 & 0 & 1 & 0 & 0 & 0 & 0 & 1 & 0 \\
\hline R15 & 1 & 0 & 1 & 0 & 0 & 0 & 1 & 0 & 0 & 1 & 0 & 0 & 0 & 0 & 1 & 0 & 1 & 0 & 1 & 1 & 1 & 0 \\
\hline R16 & 1 & 1 & 0 & 1 & 0 & 0 & 0 & 0 & 0 & 0 & 1 & 0 & 1 & 1 & 0 & 1 & 1 & 0 & 0 & 1 & 1 & 0 \\
\hline R17 & 0 & 0 & 0 & 1 & 0 & 1 & 1 & 0 & 0 & 0 & 0 & 0 & 1 & 0 & 0 & 0 & 1 & 0 & 1 & 0 & 1 & 1 \\
\hline R18 & 0 & 0 & 0 & 1 & 0 & 0 & 1 & 0 & 1 & 0 & 1 & 1 & 1 & 0 & 0 & 0 & 1 & 1 & 0 & 0 & 0 & 1 \\
\hline R19 & 0 & 0 & 0 & 0 & 1 & 1 & 1 & 0 & 0 & 1 & 0 & 0 & 0 & 0 & 1 & 0 & 0 & 1 & 1 & 0 & 1 & 1 \\
\hline R20 & 1 & 1 & 0 & 1 & 1 & 0 & 1 & 1 & 1 & 1 & 0 & 1 & 1 & 0 & 1 & 0 & 1 & 1 & 1 & 1 & 0 & 0 \\
\hline R21 & 0 & 0 & 1 & 0 & 1 & 0 & 1 & 0 & 0 & 1 & 1 & 1 & 0 & 0 & 0 & 0 & 0 & 0 & 0 & 0 & 1 & 1 \\
\hline $\mathrm{R} 22$ & 1 & 0 & 0 & 1 & 0 & 1 & 1 & 0 & 1 & 0 & 0 & 0 & 1 & 0 & 0 & 0 & 1 & 0 & 0 & 0 & 1 & 1 \\
\hline
\end{tabular}


Table A2. Final reachability matrix with transitivity check.

\begin{tabular}{|c|c|c|c|c|c|c|c|c|c|c|c|c|c|c|c|c|c|c|c|c|c|c|}
\hline & R1 & $\mathbf{R} 2$ & R3 & R4 & R5 & R6 & R7 & R8 & R9 & R10 & R11 & R12 & R13 & R14 & R15 & R16 & R17 & R18 & R19 & R20 & R21 & R22 \\
\hline R1 & 1 & $1^{*}$ & $1^{*}$ & $1^{*}$ & 1 & 1 & 1 & $1^{*}$ & 1 & 1 & 1 & $1^{*}$ & $1^{*}$ & $1^{*}$ & $1^{*}$ & $1^{*}$ & 1 & 1 & 1 & 1 & 1 & 1 \\
\hline $\mathbf{R} 2$ & $1^{*}$ & 1 & $1^{*}$ & 1 & 1 & 0 & 1 & 0 & 1 & $1^{*}$ & $1^{*}$ & $1^{*}$ & 1 & $1^{*}$ & $1^{*}$ & 1 & 1 & $1^{*}$ & $1^{*}$ & $1^{*}$ & 1 & $1^{*}$ \\
\hline R3 & $1^{*}$ & 1 & 1 & 1 & 1 & 1 & 1 & $1^{*}$ & 1 & 1 & $1^{*}$ & $1^{*}$ & $1^{*}$ & 1 & 1 & $1^{*}$ & 1 & $1^{*}$ & $1^{*}$ & 1 & 1 & 1 \\
\hline R4 & $1^{*}$ & $1^{*}$ & $1^{*}$ & 1 & 1 & 1 & 1 & $1^{*}$ & 1 & $1^{*}$ & $1^{*}$ & $1^{*}$ & $1^{*}$ & $1^{*}$ & $1^{*}$ & $1^{*}$ & $1^{*}$ & 1 & 1 & 1 & $1^{*}$ & $1^{*}$ \\
\hline R5 & $1^{*}$ & $1^{*}$ & $1^{*}$ & $1^{*}$ & 1 & 1 & 1 & 0 & 1 & 1 & $1^{*}$ & 1 & 1 & 1 & $1^{*}$ & 1 & 1 & $1^{*}$ & 1 & 1 & $1^{*}$ & 1 \\
\hline R6 & $1^{*}$ & $1^{*}$ & $1^{*}$ & $1^{*}$ & 1 & 1 & 1 & 0 & 1 & $1^{*}$ & $1^{*}$ & 1 & $1^{*}$ & $1^{*}$ & $1^{*}$ & 1 & $1^{*}$ & 1 & $1^{*}$ & $1^{*}$ & 1 & 1 \\
\hline R7 & 1 & $1^{*}$ & 1 & 1 & 1 & 0 & 1 & 0 & 1 & 1 & 1 & 1 & $1^{*}$ & $1^{*}$ & 1 & $1^{*}$ & $1^{*}$ & 1 & $1^{*}$ & $1^{*}$ & 1 & $1^{*}$ \\
\hline R8 & 1 & $1^{*}$ & 1 & 1 & 1 & $1^{*}$ & $1^{*}$ & 1 & 0 & 1 & $1^{*}$ & $1^{*}$ & 1 & $1^{*}$ & $1^{*}$ & $1^{*}$ & 1 & $1^{*}$ & $1^{*}$ & $1^{*}$ & $1^{*}$ & $1^{*}$ \\
\hline R9 & 1 & 0 & 1 & $1^{*}$ & $1^{*}$ & $1^{*}$ & $1^{*}$ & 0 & 1 & $1^{*}$ & $1^{*}$ & $1^{*}$ & 1 & 0 & 1 & $1^{*}$ & 1 & 0 & $1^{*}$ & $1^{*}$ & 1 & $1^{*}$ \\
\hline R10 & 1 & 1 & 1 & 1 & $1^{*}$ & $1^{*}$ & $1^{*}$ & 0 & $1^{*}$ & 1 & 1 & 1 & 1 & 1 & 1 & $1^{*}$ & 1 & 1 & $1^{*}$ & $1^{*}$ & 1 & 1 \\
\hline R11 & 1 & $1^{*}$ & 1 & 1 & 1 & $1^{*}$ & $1^{*}$ & 0 & 1 & 1 & 1 & 1 & 1 & 0 & 1 & 1 & 1 & 1 & $1^{*}$ & $1^{*}$ & $1^{*}$ & $1^{*}$ \\
\hline R12 & 1 & 1 & $1^{*}$ & 1 & $1^{*}$ & $1^{*}$ & 1 & $1^{*}$ & 1 & $1^{*}$ & $1^{*}$ & 1 & $1^{*}$ & $1^{*}$ & 1 & 1 & $1^{*}$ & $1^{*}$ & 1 & 1 & $1^{*}$ & 1 \\
\hline R13 & 1 & $1^{*}$ & 1 & $1^{*}$ & 1 & $1^{*}$ & $1^{*}$ & $1^{*}$ & $1^{*}$ & $1^{*}$ & $1^{*}$ & $1^{*}$ & 1 & $1^{*}$ & 1 & 1 & $1^{*}$ & $1^{*}$ & $1^{*}$ & 1 & 1 & 1 \\
\hline R14 & 1 & $1^{*}$ & $1^{*}$ & $1^{*}$ & $1^{*}$ & 0 & $1^{*}$ & 0 & 0 & $1^{*}$ & $1^{*}$ & $1^{*}$ & $1^{*}$ & 1 & 0 & 1 & $1^{*}$ & 0 & 0 & $1^{*}$ & 1 & 0 \\
\hline R15 & 1 & $1^{*}$ & 1 & $1^{*}$ & $1^{*}$ & $1^{*}$ & 1 & $1^{*}$ & $1^{*}$ & 1 & $1^{*}$ & $1^{*}$ & $1^{*}$ & 0 & 1 & 0 & 1 & $1^{*}$ & 1 & 1 & 1 & $1^{*}$ \\
\hline R16 & 1 & 1 & $1^{*}$ & 1 & $1^{*}$ & $1^{*}$ & $1^{*}$ & $1^{*}$ & $1^{*}$ & $1^{*}$ & 1 & $1^{*}$ & 1 & 1 & $1^{*}$ & 1 & 1 & $1^{*}$ & $1^{*}$ & 1 & 1 & $1^{*}$ \\
\hline R17 & 0 & 0 & $1^{*}$ & 1 & $1^{*}$ & 1 & 1 & 0 & $1^{*}$ & $1^{*}$ & $1^{*}$ & $1^{*}$ & 1 & 0 & $1^{*}$ & 0 & 1 & $1^{*}$ & 1 & 0 & 1 & 1 \\
\hline R18 & $1^{*}$ & 0 & 0 & 1 & 0 & $1^{*}$ & 1 & 0 & 1 & 0 & 1 & 1 & 1 & 0 & 0 & 0 & 1 & 1 & 0 & 0 & $1^{*}$ & 1 \\
\hline R19 & $1^{*}$ & 0 & $1^{*}$ & 0 & 1 & 1 & 1 & 0 & $1^{*}$ & 1 & $1^{*}$ & $1^{*}$ & $1^{*}$ & 0 & 1 & 0 & $1^{*}$ & 1 & 1 & 0 & 1 & 1 \\
\hline R20 & 1 & 1 & 0 & 1 & 1 & 0 & 1 & 1 & 1 & 1 & 0 & 1 & 1 & 0 & 1 & 0 & 1 & 1 & 1 & 1 & 0 & 0 \\
\hline R21 & $1^{*}$ & 0 & 1 & $1^{*}$ & 1 & $1^{*}$ & 1 & 0 & $1^{*}$ & 1 & 1 & 1 & $1^{*}$ & 0 & 0 & 0 & $1^{*}$ & 0 & 0 & 0 & 1 & 1 \\
\hline R22 & 1 & 0 & 0 & 1 & 0 & 1 & 1 & 0 & 1 & 0 & 0 & 0 & 1 & 0 & 0 & 0 & 1 & 0 & 0 & 0 & 1 & 1 \\
\hline
\end{tabular}


Table A3. Direct Relationship Matrix.

\begin{tabular}{|c|c|c|c|c|c|c|c|c|c|c|c|c|c|c|c|c|c|c|c|c|c|c|}
\hline & R1 & $\mathbf{R} 2$ & R3 & $\mathbf{R} 4$ & R5 & R6 & R7 & R8 & R9 & R10 & R11 & R12 & R13 & R14 & R15 & R16 & R17 & R18 & R19 & R20 & R21 & R22 \\
\hline R1 & 0 & 0 & 0 & 0 & 3 & 3 & 3 & 0 & 3 & 3 & 3 & 0 & 0 & 0 & 0 & 0 & 3 & 2 & 3 & 2 & 3 & 3 \\
\hline $\mathbf{R} 2$ & 0 & 0 & 0 & 3 & 3 & 0 & 3 & 0 & 3 & 0 & 0 & 0 & 3 & 0 & 0 & 2 & 2 & 0 & 0 & 0 & 3 & 0 \\
\hline R3 & 0 & 3 & 0 & 3 & 3 & 2 & 3 & 0 & 2 & 2 & 0 & 0 & 0 & 3 & 3 & 0 & 3 & 0 & 0 & 2 & 3 & 2 \\
\hline R4 & 0 & 0 & 0 & 0 & 2 & 3 & 2 & 0 & 3 & 0 & 0 & 0 & 0 & 0 & 0 & 0 & 0 & 3 & 3 & 3 & 0 & 0 \\
\hline R5 & 0 & 0 & 0 & 0 & 0 & 3 & 3 & 0 & 2 & 3 & 0 & 2 & 3 & 3 & 0 & 3 & 3 & 0 & 3 & 3 & 0 & 3 \\
\hline R6 & 0 & 0 & 0 & 0 & 3 & 0 & 3 & 0 & 3 & 0 & 0 & 3 & 3 & 0 & 0 & 3 & 0 & 2 & 0 & 0 & 3 & 3 \\
\hline R7 & 3 & 0 & 3 & 2 & 3 & 0 & 0 & 0 & 3 & 3 & 3 & 3 & 0 & 0 & 2 & 0 & 0 & 3 & 0 & 0 & 3 & 0 \\
\hline R8 & 3 & 0 & 2 & 3 & 3 & 0 & 0 & 0 & 0 & 1 & 0 & 0 & 3 & 0 & 0 & 0 & 3 & 0 & 0 & 0 & 0 & 0 \\
\hline R9 & 3 & 0 & 2 & 0 & 0 & 0 & 0 & 0 & 0 & 0 & 0 & 0 & 3 & 0 & 2 & 0 & 3 & 0 & 0 & 0 & 2 & 0 \\
\hline R10 & 3 & 3 & 2 & 1 & 0 & 0 & 0 & 0 & 0 & 0 & 2 & 3 & 3 & 2 & 3 & 0 & 3 & 3 & 0 & 0 & 3 & 3 \\
\hline R11 & 3 & 0 & 2 & 2 & 3 & 0 & 0 & 0 & 3 & 2 & 0 & 3 & 3 & 0 & 1 & 3 & 3 & 3 & 0 & 0 & 0 & 0 \\
\hline R12 & 1 & 3 & 0 & 2 & 0 & 0 & 3 & 0 & 2 & 0 & 0 & 0 & 0 & 0 & 3 & 3 & 0 & 0 & 2 & 2 & 0 & 2 \\
\hline R13 & 3 & 0 & 2 & 0 & 3 & 0 & 0 & 0 & 0 & 0 & 0 & 0 & 0 & 0 & 3 & 1 & 0 & 0 & 0 & 2 & 2 & 2 \\
\hline R14 & 3 & 0 & 0 & 0 & 0 & 0 & 0 & 0 & 0 & 0 & 0 & 0 & 0 & 0 & 0 & 3 & 0 & 0 & 0 & 0 & 3 & 0 \\
\hline R15 & 2 & 0 & 2 & 0 & 0 & 0 & 2 & 0 & 0 & 3 & 0 & 0 & 0 & 0 & 0 & 0 & 3 & 0 & 3 & 3 & 3 & 0 \\
\hline R16 & 3 & 2 & 0 & 3 & 0 & 0 & 0 & 0 & 0 & 0 & 3 & 0 & 1 & 3 & 0 & 0 & 2 & 0 & 0 & 3 & 3 & 0 \\
\hline R17 & 0 & 0 & 0 & 2 & 0 & 3 & 3 & 0 & 0 & 0 & 0 & 0 & 2 & 0 & 0 & 0 & 0 & 0 & 2 & 0 & 2 & 3 \\
\hline R18 & 0 & 0 & 0 & 3 & 0 & 0 & 3 & 0 & 2 & 0 & 3 & 2 & 3 & 0 & 0 & 0 & 3 & 0 & 0 & 0 & 0 & 3 \\
\hline R19 & 0 & 0 & 0 & 0 & 3 & 3 & 2 & 0 & 0 & 2 & 0 & 0 & 0 & 0 & 3 & 0 & 0 & 1 & 0 & 0 & 3 & 3 \\
\hline R20 & 2 & 2 & 0 & 3 & 3 & 0 & 3 & 3 & 3 & 3 & 0 & 2 & 2 & 0 & 3 & 0 & 3 & 1 & 1 & 0 & 0 & 0 \\
\hline R21 & 0 & 0 & 3 & 0 & 1 & 0 & 3 & 0 & 0 & 3 & 3 & 3 & 0 & 0 & 0 & 0 & 0 & 0 & 0 & 0 & 0 & 3 \\
\hline R22 & 3 & 0 & 0 & 3 & 0 & 3 & 2 & 0 & 2 & 0 & 0 & 0 & 2 & 0 & 0 & 0 & 3 & 0 & 0 & 0 & 3 & 0 \\
\hline
\end{tabular}




\section{Appendix B}

Table A4. Level I of risk variables.

\begin{tabular}{|c|c|c|c|c|}
\hline Variable & Reachability Set & Antecedent Set & Intersection & Level \\
\hline R1 & $1,2,3,4,5,6,7,8,9,10,11,12,13,14,15,16,17,18,19,20,21,22$ & $1,2,3,4,5,6,7,8,9,10,11,12,13,14,15,16,18,19,20,21,22$ & $1,2,3,4,5,6,7,8,9,10,11,12,13,14,15,16,18,19,20,21,22$ & \\
\hline R2 & $1,2,3,4,5,6,7,9,10,11,12,13,14,15,16,17,18,19,20,21,22$ & $1,2,3,4,5,6,7,8,10,11,12,13,14,15,16,20$ & $1,2,3,4,5,6,7,10,11,12,13,14,15,16,20$ & \\
\hline R3 & $1,2,3,4,5,6,7,8,9,10,11,12,13,14,15,16,17,18,19,20,21,22$ & $1,2,3,4,5,6,7,8,9,10,11,12,13,14,15,16,17,19,21$ & $1,2,3,4,5,6,7,8,9,10,11,12,13,14,15,16,17,19,20,21,22$ & \\
\hline R4 & $1,2,3,4,5,6,7,8,9,10,11,12,13,14,15,16,17,18,19,20,21,22$ & $1,2,3,4,5,6,7,8,9,10,11,12,13,14,15,16,17,18,20,21,22$ & $1,2,3,4,5,6,7,8,9,10,11,12,13,14,15,16,17,18,20,21,22$ & \\
\hline R6 & $1,2,3,4,5,6,7,9,10,11,12,13,14,15,16,17,18,19,20,21,22$ & $1,2,3,4,5,6,8,9,10,11,12,13,15,16,17,18,19,21,22$ & $1,2,3,4,5,6,9,10,11,12,13,15,16,17,18,19,21,22$ & \\
\hline R7 & $1,2,3,4,5,7,9,10,11,12,13,14,15,16,17,18,19,20,21,22$ & $1,2,3,4,5,6,7,8,9,10,11,12,13,14,15,16,17,18,19,20,21,22$ & $1,2,3,4,5,7,9,10,11,12,13,14,15,16,17,18,19,20,21,22$ & L1 \\
\hline R8 & $1,2,3,4,5,6,7,8,10,11,12,13,14,15,16,17,18,19,20,21,22$ & $1,3,4,8,12,13,15,16,20$ & $1,3,4,8,12,13,15,16,20$ & \\
\hline R9 & $1,3,4,5,6,7,9,10,11,12,13,15,16,17,19,20,21,22$ & $1,2,3,4,5,6,7,9,10,11,12,13,15,16,17,18,19,20,21,22$ & $1,3,4,5,6,7,9,10,11,12,13,15,16,17,19,20,21,22$ & L1 \\
\hline R10 & $1,2,3,4,5,6,7,9,10,11,12,13,14,15,16,17,18,19,20,21,22$ & $1,2,3,4,5,6,7,8,9,10,11,12,13,14,15,16,17,19,20,21$ & $1,2,3,4,5,6,7,9,10,11,12,13,14,15,16,17,19,20,21$ & \\
\hline R12 & $1,2,3,4,5,6,7,8,9,10,11,12,13,14,15,16,17,18,19,20,21,22$ & $1,2,3,4,5,6,7,8,9,10,11,12,13,14,15,16,17,18,19,20,21$ & $1,2,3,4,5,6,7,8,9,10,11,12,13,14,15,16,17,18,19,20,21$ & \\
\hline R13 & $1,2,3,4,5,6,7,8,9,10,11,12,13,14,15,16,17,18,19,20,21,22$ & $1,2,3,4,5,6,7,8,9,10,11,12,13,14,15,16,17,18,19,20,21,22$ & $1,2,3,4,5,6,7,8,9,10,11,12,13,14,15,16,17,18,19,20,21,22$ & L1 \\
\hline R14 & $1,2,3,4,5,7,10,11,12,13,14,16,17,20,21$ & $1,2,3,4,5,6,7,8,10,12,13,14,16$ & $1,2,3,4,5,7,10,12,13,14,16$ & \\
\hline R15 & $1,2,3,4,5,6,7,8,9,10,11,12,13,15,17,18,19,20,21,22$ & $1,2,3,4,5,6,7,8,9,10,11,12,13,15,16,17,19,20$ & $1,2,3,4,5,6,7,8,9,10,11,12,13,15,17,19,20$ & \\
\hline R16 & $1,2,3,4,5,6,7,8,9,10,11,12,13,14,15,16,17,18,19,20,21,22$ & $1,2,3,4,5,6,7,8,9,10,11,12,13,14,16$ & $1,2,3,4,5,6,7,8,9,10,11,12,13,14,16$ & \\
\hline R17 & $3,4,5,6,7,9,10,11,12,13,15,17,18,19,21,22$ & $1,2,3,4,5,6,7,8,9,10,11,12,13,14,15,16,17,18,19,20,21,22$ & $3,4,5,6,7,9,10,11,12,13,15,17,18,19,21,22$ & L1 \\
\hline R18 & $1,4,6,7,9,11,12,13,17,18,21,22$ & $1,2,3,4,5,6,7,8,10,11,12,13,15,16,17,18,19,20$ & $1,4,6,7,11,12,13,17,18$ & \\
\hline R19 & $1,3,5,6,7,9,10,11,12,13,15,17,18,19,21,22$ & $1,2,3,4,5,6,7,8,9,10,11,12,13,15,16,17,19,20$ & $1,3,5,6,7,9,10,11,12,13,15,17,19$ & \\
\hline R20 & $1,2,4,5,7,8,9,10,12,13,15,17,18,19,20$ & $1,2,3,4,5,6,7,8,9,10,11,12,13,14,15,16,20$ & $1,2,4,5,7,8,9,10,12,13,15,20$ & \\
\hline $\mathbf{R} 21$ & $1,3,4,5,6,7,9,10,11,12,13,17,21,22$ & $1,2,3,4,5,6,7,8,9,10,11,12,13,14,15,16,17,18,19,21,22$ & $1,3,4,5,6,7,9,10,11,12,13,17,21,22$ & L1 \\
\hline R22 & $1,4,6,7,9,13,17,21,22$ & $1,2,3,4,5,6,7,8,9,10,11,12,13,15,16,17,18,19,21,22$ & $1,4,6,7,9,13,17,21,22$ & L1 \\
\hline
\end{tabular}


Table A5. Level II of risk variables.

\begin{tabular}{clll}
\hline Variable & \multicolumn{1}{c}{ Reachability Set } & \multicolumn{1}{c}{ Antecedent Set } & \multicolumn{1}{c}{ Intersection } \\
\hline R1 & $1,2,3,4,5,6,8,10,11,12,14,15,16,18,19,20$ & $1,2,3,4,5,6,8,10,11,12,14,15,16,18,19,20$ & $1,2,3,4,5,6,8,10,11,12,14,15,16,18,19,20$ \\
R2 & $1,2,3,4,5,6,10,11,12,14,15,16,18,19,20$ & $1,2,3,4,5,6,8,10,11,12,14,15,16,20$ & $1,2,3,4,5,6,10,11,12,14,15,16,20$ \\
R3 & $1,2,3,4,5,6,8,10,11,12,14,15,16,18,19,20$ & $1,2,3,4,5,6,8,10,11,12,14,15,16,19$ & $1,2,3,4,5,6,8,10,11,12,14,15,16,19,20$ \\
R4 & $1,2,3,4,5,6,8,10,11,12,14,15,16,18,19,20$ & $1,2,3,4,5,6,8,10,11,12,14,15,16,18,20$ & $1,2,3,4,5,6,8,10,11,12,14,15,16,18,20$ \\
R5 & $1,2,3,4,5,6,10,11,12,14,15,16,18,19,20$ & $1,2,3,4,5,6,8,10,11,12,14,15,16,19,20$ & $1,2,3,4,5,6,10,11,12,14,15,16,19,20$ \\
R6 & $1,2,3,4,5,6,10,11,12,14,15,16,18,19,20$ & $1,2,3,4,5,6,8,10,11,12,15,16,18,19$ & $1,2,3,4,5,6,10,11,12,15,16,18,19$ \\
R8 & $1,2,3,4,5,6,8,10,11,12,14,15,16,18,19,20$ & $1,3,4,8,12,15,16,20$ & $1,3,4,8,12,15,16,20$ \\
R10 & $1,2,3,4,5,6,10,11,12,14,15,16,18,19,20$ & $1,2,3,4,5,6,8,10,11,12,14,15,16,19,20$ & $1,2,3,4,5,6,10,11,12,14,15,16,19,20$ \\
R11 & $1,2,3,4,5,6,10,11,12,15,16,18,19,20$ & $1,2,3,4,5,6,8,10,11,12,14,15,16,18,19$ & $1,2,3,4,5,6,10,11,12,15,16,18,19$ \\
R12 & $1,2,3,4,5,6,8,10,11,12,14,15,16,18,19,20$ & $1,2,3,4,5,6,8,10,11,12,14,15,16,18,19,20$ & $1,2,3,4,5,6,8,10,11,12,14,15,16,18,19,20$ \\
R14 & $1,2,3,4,5,10,11,12,14,16,20$ & $1,2,3,4,5,6,8,10,12,14,16$ & $1,2,3,4,5,10,12,14,16$ \\
R15 & $1,2,3,4,5,6,8,10,11,12,15,18,19,20$ & $1,2,3,4,5,6,8,10,11,12,15,16,19,20$ & $1,2,3,4,5,6,8,10,11,12,15,19,20$ \\
R16 & $1,2,3,4,5,6,8,10,11,12,14,15,16,18,19,20$ & $1,2,3,4,5,6,8,10,11,12,14,16$ & $1,2,3,4,5,6,8,10,11,12,14,16$ \\
R18 & $1,4,6,11,12,18$ & $1,2,3,4,5,6,8,10,11,12,15,16,18,19,20$ & $1,4,6,11,12,18$ \\
R19 & $1,3,5,6,10,11,12,15,18,19$ & $1,2,3,4,5,6,8,10,11,12,15,16,19,20$ & $1,3,5,6,10,11,12,15,19$ \\
R20 & $1,2,4,5,8,10,12,15,18,19,20$ & $1,2,3,4,5,6,8,10,11,12,14,15,16,20$ & $1,2,4,5,8,10,12,15,20$ \\
\hline
\end{tabular}

Table A6. Level III of risk variables.

\begin{tabular}{clll}
\hline Variable & \multicolumn{1}{c}{ Reachability Set } & \multicolumn{1}{c}{ Antecedent Set } & \multicolumn{1}{c}{ Level } \\
\hline R2 & $2,3,4,5,6,10,11,14,15,16,19,20$ & $2,3,4,5,6,8,10,11,14,15,16,20$ & $2,3,4,5,6,10,11,14,15,16,20$ \\
R3 & $2,3,4,5,6,8,10,11,14,15,16,19,20$ & $2,3,4,5,6,8,10,11,14,15,16,19$ & $2,3,4,5,6,8,10,11,14,15,16,19,20$ \\
R4 & $2,3,4,5,6,8,10,11,14,15,16,19,20$ & $2,3,4,5,6,8,10,11,14,15,16,20$ & $2,3,4,5,6,8,10,11,14,15,16,20$ \\
R5 & $2,3,4,5,6,10,11,14,15,16,19,20$ & $2,3,4,5,6,8,10,11,14,15,16,19,20$ & $2,3,4,5,6,10,11,14,15,16,19,20$ \\
R6 & $2,3,4,5,6,10,11,14,15,16,19,20$ & $2,3,4,5,6,8,10,11,15,16,19$ & $2,3,4,5,6,10,11,15,16,19$ \\
R8 & $2,3,4,5,6,8,10,11,14,15,16,19,20$ & $3,4,8,15,16,20$ & $3,4,8,15,16,20$ \\
R10 & $2,3,4,5,6,10,11,14,15,16,19,20$ & $2,3,4,5,6,8,10,11,14,15,16,19,20$ & $2,3,4,5,6,10,11,14,15,16,19,20$ \\
R11 & $2,3,4,5,6,10,11,15,16,19,20$ & $2,3,4,5,6,8,10,11,14,15,16,19$ & $2,3,4,5,6,10,11,15,16,19$ \\
R14 & $2,3,4,5,10,11,14,16,20$ & $2,3,4,5,6,8,10,14,16$ & $2,3,4,5,10,14,16$ \\
R15 & $2,3,4,5,6,8,10,11,15,19,20$ & $2,3,4,5,6,8,10,11,15,16,19,20$ & $2,3,4,5,6,8,10,11,15,19,20$ \\
R16 & $2,3,4,5,6,8,10,11,14,15,16,19,20$ & $2,3,4,5,6,8,10,11,14,16$ & $2,3,4,5,6,8,10,11,14,16$ \\
R19 & $3,5,6,10,11,15,19$ & $2,3,4,5,6,8,10,11,15,16,19,20$ & $3,5,6,10,11,15,19$ \\
R20 & $2,4,5,8,10,15,19,20$ & $2,3,4,5,6,8,10,11,14,15,16,20$ & $2,4,5,8,10,15,20$ \\
\hline
\end{tabular}


Table A7. Level IV of risk variables.

\begin{tabular}{clllc}
\hline Variable & \multicolumn{1}{c}{ Reachability Set } & Antecedent Set & \multicolumn{1}{c}{ Intersection } & Level \\
\hline R2 & $2,4,6,11,14,16,20$ & $2,4,6,8,11,14,16,20$ & $2,4,6,11,14,16,20$ & L4 \\
R4 & $2,4,6,8,11,14,16,20$ & $2,4,6,8,11,14,16,20$ & $2,4,6,8,11,14,16,20$ & L4 \\
R6 & $2,4,6,11,14,16,20$ & $2,4,6,8,11,16$ & $2,4,6,11,16$ & \\
R8 & $2,4,6,8,11,14,16,20$ & $4,8,16,20$ & $4,8,16,20$ & \\
R11 & $2,4,6,11,16,20$ & $2,4,6,8,11,14,16$ & $2,4,6,11,16$ & \\
R14 & $2,4,11,14,16,20$ & $2,4,6,8,14,16$ & $2,4,14,16$ & \\
R16 & $2,4,6,8,11,14,16,20$ & $2,4,6,8,11,14,16$ & $2,4,6,8,11,14,16$ & \\
R20 & $2,4,8,20$ & $2,4,6,8,11,14,16,20$ & $2,4,8,20$ & L4 \\
\hline
\end{tabular}

Table A8. Level V of risk variables.

\begin{tabular}{cllll}
\hline Variable & Reachability Set & \multicolumn{1}{c}{ Antecedent Set } & Intersection & Level \\
\hline R6 & $6,11,14,16$ & $6,8,11,16$ & $6,11,16$ & \\
R8 & $6,8,11,14,16$ & 8,16 & 8,16 & \\
R11 & $6,11,16$ & $6,8,11,14,16$ & $6,11,16$ & L5 \\
R14 & $11,14,16$ & $6,8,14,16$ & 14,16 & \\
R16 & $6,8,11,14,16$ & $6,8,11,14,16$ & $6,8,11,14,16$ & L5 \\
\hline
\end{tabular}

Table A9. Level VI of risk variables.

\begin{tabular}{cllll}
\hline Variable & Reachability Set & Antecedent Set & Intersection & Level \\
\hline R6 & 6,14 & 6,8 & 6 & \\
R8 & $6,8,14$ & 8 & 8 & \\
R14 & 14 & $6,8,14$ & 14 & L6 \\
\hline
\end{tabular}

Table A10. Levels VII and VIII of risk variables.

\begin{tabular}{clllc}
\hline Variable & Reachability Set & Antecedent Set & Intersection & Level \\
\hline R6 & 6 & 6,8 & 6 & L7 \\
R8 & 6,8 & 8 & 8 & L8 \\
\hline
\end{tabular}

\section{References}

1. Pottmaier, D.; Melo, C.R.; Sartor, M.N.; Kuester, S.; Amadio, T.M.; Fernandes, C.A.H.; Marinha, D.; Alarcon, O.E. The Brazilian energy matrix: From a materials science and engineering perspective. Renew. Sustain. Energy Rev. 2013, 19, 678-691. [CrossRef]

2. Martins, F.R.; Pereira, E.B. Enhancing information for solar and wind energy technology deployment in Brazil. Energy Pol. 2011, 39, 4378-4390. [CrossRef]

3. Lappe, M.; Spang, K. Investments in project management are profitable: A case study-based analysis of the relationship between the costs and benefits of project management. Int. J. Proj. Manag. 2014, 32, 603-612. [CrossRef]

4. Chopra, S.; Meindl, P. Supply Chain Management: Strategy, Planning, and Operation, Global Edition, 6th ed.; Pearson: London, UK, 2015.

5. Da Silva, N.F.; Rosa, L.P.; Freitas, M.A.V.; Pereira, M.G. Wind energy in Brazil: From the power sector's expansion crisis model to the favorable environment. Renew. Sustain. Energy Rev. 2013, 22, 686-697. [CrossRef]

6. Schmidt, J.; Cancella, R.; Junior, A.O.P. The effect of windpower on long-term variability of combined hydro-wind resources: The case of Brazil. Renew. Sustain. Energy Rev. 2016, 55, 131-141. [CrossRef]

7. Gatzert, N.; Kosub, T. Risks and risk management of renewable energy projects: The case of onshore and offshore wind parks. Renew. Sustain. Energy Rev. 2016, 60, 982-998. [CrossRef]

8. Jin, X.; Zhang, Z.; Shi, X.; Ju, W. A review on wind power industry and corresponding insurance market in China: Current status and challenges. Renew. Sustain. Energy Rev. 2014, 38, 1069-1082. [CrossRef] 
9. Liebreich, M. Financing RE: Risk management in financing renewable energy projects. Refocus 2005, 6, 18-20. [CrossRef]

10. Montes, G.M.; Martín, E.P. Profitability of wind energy: Short-term risk factors and possible improvements. Renew. Sustain. Energy Rev. 2007, 11, 2191-2200. [CrossRef]

11. Malhotra, Y. Advancing Cyber Risk Insurance Underwriting Model Risk Management Beyond VaR to Pre-Empt and Prevent the Forthcoming Global Cyber Insurance Crisis; Social Science Research Network: Rochester, NY, USA, 2017.

12. Carreño, M.L.; Cardona, O.D.; Barbat, A.H. A disaster risk management performance index. Nat. Hazards 2007, 41, 1-20. [CrossRef]

13. Thomalla, F.; Boyland, M.; Johnson, K.; Ensor, J.; Tuhkanen, H.; Gerger Swartling, Å.; Han, G.; Forrester, J.; Wahl, D. Transforming development and disaster risk. Sustainability 2018, 10, 1458. [CrossRef]

14. Teller, J.; Kock, A.; Gemünden, H.G. Risk management in project portfolios is more than managing project risks: A contingency perspective on risk management. Proj. Manag. J. 2014, 45, 67-80. [CrossRef]

15. Belluz, D.D.B. Operational risk management. In Enterprise Risk Management; Wiley-Blackwell: Hoboken, NJ, USA, 2011; pp. 279-301. ISBN 978-1-118-26708-0.

16. Park, C.; Han, S.; Lee, K.-W.; Lee, Y.; Park, C.Y.; Han, S.H.; Lee, K.-W.; Lee, Y.M. Analyzing drivers of conflict in energy infrastructure projects: Empirical case study of natural gas pipeline sectors. Sustainability 2017, 9, 2031. [CrossRef]

17. Pfohl, H.-C.; Köhler, H.; Thomas, D. State of the art in supply chain risk management research: Empirical and conceptual findings and a roadmap for the implementation in practice. Logist. Res. 2010, 2, 33-44. [CrossRef]

18. Crouhy, M.; Mark, R.; Galai, D. Risk Management, 1st ed.; McGraw-Hill Education: New York, NY, USA, 2000; ISBN 978-0-07-135731-9.

19. Lee, H.L.; Whang, S. Higher supply chain security with lower cost: Lessons from total quality management. Int. J. Produc. Econ. 2005, 96, 289-300. [CrossRef]

20. Simchi-Levi, D.; Vassiliadis, C.G.; Kyratzoglou, I.M. MIT Forum for Supply Chain Innovation Report 2013: Supply Chain and Risk Management. Available online: http:/ / supplychain.mit.edu/events/Forum-PwCReport (accessed on 15 March 2016).

21. Jüttner, U.; Peck, H.; Christopher, M. Supply chain risk management: Outlining an agenda for future research. Int. J. Logist. Res. Appl. 2003, 6, 197-210. [CrossRef]

22. Christopher, M.; Peck, H. Building the resilient supply chain. Int. J. Logist. Manag. 2004, 15, 1-14. [CrossRef]

23. Chopra, S.; Sodhi, M.S. Supply-chain breakdown. MIT Sloan Manag. Rev. 2004, 46, 53-61.

24. Xinyao, J.; Yongjun, H.; Fuchao, L. Research on the evaluation of wind power projects of investment risk. Procedia Comput. Sci. 2017, 111, 388-398. [CrossRef]

25. Neto, D.P.; Domingues, E.G.; Calixto, W.P.; Alves, A.J. Methodology of investment risk analysis for wind power plants in the brazilian free market. Electr. Power Compon. Syst. 2018, 46, 316-330. [CrossRef]

26. Li, H.; Wu, L. Analysis of financial support efficiency for China's wind power industry. Energy Sources Part $B$ Econ. Plan. Policy 2016, 11, 1035-1041. [CrossRef]

27. Simas, M.; Pacca, S. Assessing employment in renewable energy technologies: A case study for wind power in Brazil. Renew. Sustain. Energy Rev. 2014, 31, 83-90. [CrossRef]

28. Goudarzi, N.; Zhu, W.D. A review on the development of wind turbine generators across the world. Int. J. Dyn. Control 2013, 1, 192-202. [CrossRef]

29. Madavar, M.D.; Nezhad, M.H.G.; Aslani, A.; Naaranoja, M. Analysis of generations of wind power technologies based on technology life cycle approach. Distrib. Gener. Altern. Energy J. 2017, 32, 52-79. [CrossRef]

30. Gorayeb, A.; Brannstrom, C.; de Andrade Meireles, A.J.; de Sousa Mendes, J. Wind power gone bad: Critiquing wind power planning processes in northeastern Brazil. Energy Res. Soc. Sci. 2018, 40, 82-88. [CrossRef]

31. Juárez, A.A.; Araújo, A.M.; Rohatgi, J.S.; de Oliveira Filho, O.D.Q. Development of the wind power in Brazil: Political, social and technical issues. Renew. Sustain. Energy Rev. 2014, 39, 828-834. [CrossRef]

32. Poulsen, T.; Lema, R. Is the supply chain ready for the green transformation? The case of offshore wind logistics. Renew. Sustain. Energy Rev. 2017, 73, 758-771. [CrossRef]

33. Prostean, G.; Badea, A.; Vasar, C.; Octavian, P. Risk variables in wind power supply Chain. Procedia Soc. Behav. Sci. 2014, 124, 124-132. [CrossRef] 
34. AbdelWarith, K.A.; Anastasopoulos, P.C.; Richardson, W.; Fricker, J.D.; Haddock, J.E. Design of local roadway infrastructure to service sustainable energy facilities. Energy Sustain. Soc. 2014, 4, 14. [CrossRef]

35. Gonzalez, E.; Nanos, E.M.; Seyr, H.; Valldecabres, L.; Yürüşen, N.Y.; Smolka, U.; Muskulus, M.; Melero, J.J. Key performance indicators for wind farm operation and maintenance. Energy Procedia 2017, 137, 559-570. [CrossRef]

36. Chou, J.-S.; Ou, Y.-C.; Lin, K.-Y.; Wang, Z.-J. Structural failure simulation of onshore wind turbines impacted by strong winds. Eng. Struct. 2018, 162, 257-269. [CrossRef]

37. Kandil, K.S.A.; Saudi, G.N.; Eltaly, B.A.-A.; El-khier, M.M.A. Seismic response of a full-scale wind turbine tower using experimental and numerical modal analysis. Int. J. Adv. Struct. Eng. 2016, 8, 337-349. [CrossRef]

38. Laouti, N.; Othman, S.; Alamir, M.; Sheibat-Othman, N. Combination of model-based observer and support vector machines for fault detection of wind turbines. Int. J. Autom. Comput. 2014, 11, 274-287. [CrossRef]

39. Ren, G.; Liu, J.; Wan, J.; Guo, Y.; Yu, D. Overview of wind power intermittency: Impacts, measurements, and mitigation solutions. Appl. Energy 2017, 204, 47-65. [CrossRef]

40. de Lucena, A.F.P.; Szklo, A.S.; Schaeffer, R.; Dutra, R.M. The vulnerability of wind power to climate change in Brazil. Renew. Energy 2010, 35, 904-912. [CrossRef]

41. Liu, X.; Xu, Z.; Wong, K.P. Recent advancement on technical requirements for grid integration of wind power. J. Mod. Power Syst. Clean Energy 2013, 1, 216-222. [CrossRef]

42. Skarin, A.; Nellemann, C.; Rönnegård, L.; Sandström, P.; Lundqvist, H. Wind farm construction impacts reindeer migration and movement corridors. Landsc. Ecol. 2015, 30, 1527-1540. [CrossRef]

43. Valença, R.B.; Bernard, E. Another blown in the wind: Bats and the licensing of wind farms in Brazil. Nat. Conservação 2015, 13, 117-122. [CrossRef]

44. Xiang, Y.; Wang, L.; Liu, N. Coordinated attacks on electric power systems in a cyber-physical environment. Electr. Power Syst. Res. 2017, 149, 156-168. [CrossRef]

45. Olsen, S.A. Interpretive structural modeling. In Group Planning and Problem Solving Methods in Engineering Management; John Wiley and Sons, Inc.: New York, NY, USA, 1982.

46. Sushil, S. Interpreting the interpretive structural model. Glob. J. Flex. Syst. Manag. 2012, 13, 87-106. [CrossRef]

47. Chandramowli, S.; Transue, M.; Felder, F.A. Analysis of barriers to development in landfill communities using interpretive structural modeling. Habitat Int. 2011, 35, 246-253. [CrossRef]

48. Manuj, I.; Mentzer, J.T. Global supply chain risk management strategies. Int. J. Phys. Distrib. Logist. Manag. 2008, 38, 192-223. [CrossRef]

49. Pfohl, H.-C.; Gallus, P.; Thomas, D. Interpretive structural modeling of supply chain risks. Int. J. Phys. Distrib. Logist. Manag. 2011, 41, 839-859. [CrossRef]

50. Tummala, R.; Schoenherr, T. Assessing and managing risks using the supply chain risk management process (SCRMP). Supply Chain Manag. Int. J. 2011, 16, 474-483. [CrossRef]

51. Nishat Faisal, M.; Banwet, D.K.; Shankar, R. Supply chain risk mitigation: Modeling the enablers. Bus. Process Manag. J. 2006, 12, 535-552. [CrossRef]

52. Olson, D.L.; Wu, D. Risk management models for supply chain: A scenario analysis of outsourcing to China. Supply Chain Manag. Int. J. 2011, 16, 401-408. [CrossRef]

53. Saxena, J.P.; Vrat, P. Impact of indirect relationships in classification of variables-A micmac analysis for energy conservation. Syst. Res. 1990, 7, 245-253. [CrossRef]

54. Dubey, R.; Ali, S.S. Identification of flexible manufacturing system dimensions and their interrelationship using total interpretive structural modelling and fuzzy MICMAC analysis. Glob. J. Flex. Syst. Manag. 2014, 15, 131-143. [CrossRef]

55. Ravi, V.; Shankar, R. Analysis of interactions among the barriers of reverse logistics. Technol. Forecast. Soc. Chang. 2005, 72, 1011-1029. [CrossRef]

56. Lamming, R.; Hampson, J. The environment as a supply chain management issue. Br. J. Manag. 1996, 7, S45-S62. [CrossRef]

57. Gorane, S.J.; Kant, R. Supply chain management: Modelling the enablers using ISM and fuzzy MICMAC approach. Int. J. Logist. Syst. Manag. 2013, 16, 147-166. [CrossRef]

58. Bag, S.; Anand, N. Modeling green supply chain management framework using ISM and MICMAC analysis. Afr. J. Bus. Manag. 2014, 8, 1053-1065. [CrossRef] 
59. Khan, S.; Haleem, A.; Khan, M.; Abidi, M.; Al-Ahmari, A.; Khan, S.; Haleem, A.; Khan, M.I.; Abidi, M.H.; Al-Ahmari, A. Implementing traceability systems in specific supply chain management (SCM) through critical success factors (CSFs). Sustainability 2018, 10, 204. [CrossRef]

60. Brüggen, E.; Willems, P. A Critical comparison of offline focus groups, online focus groups and E.-Delphi. Int. J. Mark. Res. 2009, 51, 1-15. [CrossRef]

61. Hasson, F.; Keeney, S.; McKenna, H. Research guidelines for the Delphi survey technique. J. Adv. Nurs. 2000, 32, 1008-1015. [CrossRef] [PubMed]

62. Linstone, H.A.; Turoff, M. The Delphi Method; Addison-Wesley Reading: Boston, MA, USA, 1975.

63. Loveridge, D. Experts and foresight: Review and experience. Int. J. Foresight Innov. Policy 2004, 1, 33. [CrossRef]

64. La Prospective: Downloading the Applications. Available online: http://en.laprospective.fr/methodsof-prospective/downloading-the-applications/download/YREUj6TAZ56msz0v0VS7/johan.veltmeyer@ bigpond.com (accessed on 3 August 2018).

(C) 2018 by the authors. Licensee MDPI, Basel, Switzerland. This article is an open access article distributed under the terms and conditions of the Creative Commons Attribution (CC BY) license (http://creativecommons.org/licenses/by/4.0/). 